\title{
The Impacts of Wildfires on Ozone Production and Boundary Layer Dynamics in California's Central Valley
}

Keming Pan and Ian C. Faloona

Department of Land, Air, \& Water Resources and the Air Quality Research Center, University of California, Davis

Correspondence to: Keming Pan (kmpan@ucdavis.edu)

\begin{abstract}
We investigate the role of wildfire smoke on ozone photochemical production $\left(\mathrm{P}\left(\mathrm{O}_{3}\right)\right)$ and atmospheric boundary layer (ABL) dynamics in California's Central Valley during June-September, 2016-2020. Wildfire events are identified by the Hazard Mapping System (HMS) and Hybrid Single Particle Lagrangian Integrated Trajectory Model (HYSPLIT). Air quality and meteorological data are analyzed from 10 monitoring sites operated by the California Air Resources Board (CARB) across the Central Valley. On average, wildfires were found to influence air quality in the Central Valley on about $20 \%$ of the total summer days of the study. During wildfire influenced periods, maximum daily $8 \mathrm{~h}$ averaged (MDA8) $\mathrm{O}_{3}$ was enhanced by about $5.5 \mathrm{ppb}$ or $10 \%$ of the median MDA8 (once corrected for the slightly warmer temperatures) over the entire valley. Overall, nearly half of the total exceedances of the National Ambient Air Quality Standards (NAAQS) where MDA8 $\mathrm{O}_{3}>70 \mathrm{ppb}$, occur under the influence of wildfires, and approximately $10 \%$ of those were in exceedance by 5 ppb or less indicating circumstances that would have been in compliance with the NAAQS were it not for wildfire emissions. The photochemical ozone production rate calculated from the modified Leighton relationship was also found to be higher by $26 \%$ on average compared to non-fire periods despite the average diminution of $j\left(\mathrm{NO}_{2}\right)$ by $\sim 7 \%$ due to the shading effect of the wildfire smoke plumes. Furthermore, the in-situ ozone production rates are found to be elevated due to enhancement of both peroxy radicals and NO in near equal measure. Surface heat flux measurements from two AmeriFlux sites in the Northern San Joaquin Valley show midday surface buoyancy fluxes decrease by $30 \%$ on average when influenced by wildfire smoke. Similarly, afternoon peak ABL heights measured from a radio acoustic sounding system (RASS) located in Visalia in the Southern San Joaquin Valley were found to decrease on average by $80 \mathrm{~m}(\sim 15 \%)$ with a concomitant reduction of downwelling shortwave radiation of $54 \mathrm{Wm}^{-2}$, consistent with past observations of the dependence of boundary layer heights on insolation.
\end{abstract}

Keywords Boundary Layer Dynamics · California's Central Valley · Ozone Photochemistry · Wildfire · NAAQS

\section{Introduction}

Ozone $\left(\mathrm{O}_{3}\right)$ pollution poses a threat to public health and the environment. Excessive $\mathrm{O}_{3}$ exposure is known to damage the tissues of the respiratory tract causing a variety of symptoms such as chest pain, coughing, emphysema, asthma, and leading to the need for increased medical care (Rombout et al., 1986). Apart from that, $\mathrm{O}_{3}$ also causes substantial damage to crops, forests, and native plants (Ainsworth, 2017). Tropospheric $\mathrm{O}_{3}$ is produced from the chemical reaction of nitrogen oxides 


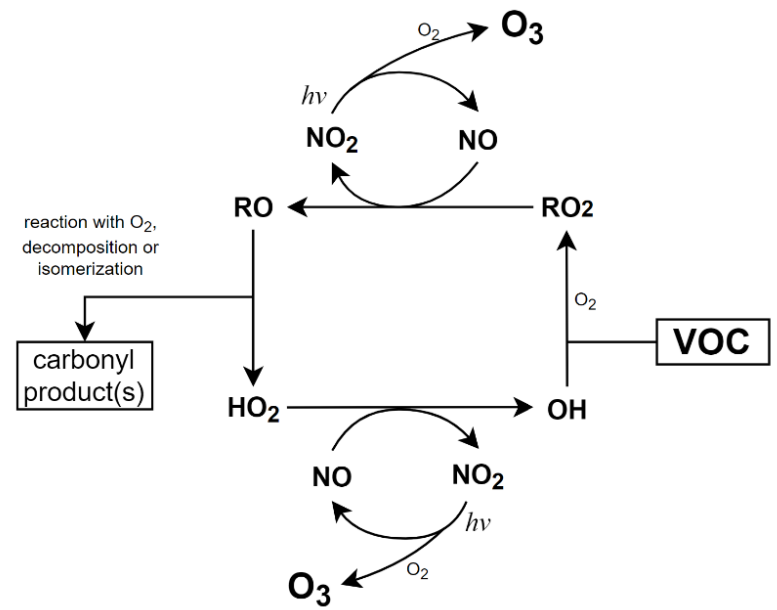

Figure 1: Schematic representation of the photochemical formation of $\mathrm{O}_{3}$ in the presence of $\mathrm{NO}_{\mathrm{x}}$ and VOCs (Jenkin \& Hayman, 1999).

$\mathrm{NO}_{2}+h v \rightarrow \mathrm{NO}+\mathrm{O}\left({ }^{3} P\right)$

$\mathrm{O}_{3}+\mathrm{NO} \rightarrow \mathrm{NO}_{2}+\mathrm{O}_{2}$

$\mathrm{HO}_{2}+\mathrm{NO} \rightarrow \mathrm{NO}_{2}+\mathrm{OH}$

$\mathrm{RO}_{2}+\mathrm{NO} \rightarrow \mathrm{NO}_{2}+\mathrm{RO}$

$\mathrm{O}_{2}+\mathrm{O}\left({ }^{3} P\right)+M \rightarrow \mathrm{O}_{3}+M$

Wildfires emit large amounts of primary pollutants, like black carbon (BC), carbon monoxide (CO), $\mathrm{NO}_{\mathrm{x}}$ and VOCs. Studies of boreal fire emissions show that the $\mathrm{NO}_{\mathrm{x}}$ concentrations can be doubled, and $\mathrm{BC}$ increased by 10 times when influenced by wildfires, even 1-2 weeks downwind in the middle of the Atlantic Ocean (Val Martín et al., 2006). The wildfire impacts on $\mathrm{O}_{3}$ production is a complex process involving various factors, such as fire precursor emissions, altered photochemical reactions, the effect on radiation by aerosols from the smoke plume, and local and downwind meteorological patterns (Jaffe and Wigder et al., 2012). Previous studies indicate that both $\mathrm{NO}_{\mathrm{x}}$ and VOCs emissions from wildfires influence the $\mathrm{O}_{3}$ budgets downwind, with enhancements ranging from 5 to 20 ppb (Baylon et al., 2015; Buysse et al., 2019; Jaffe and Wigder et al., 2012; McClure et al., 2018; Selimovic et al., 2020; Val Martín et al., 2006). When wildfire smoke

50 reaches urban regions, the $\mathrm{NO}_{x}$, and VOCs in the smoke is believed to enhance $\mathrm{O}_{3}$ production (Akagi et al., 2013; Singh et al., 2012) and exacerbate the already problematic $\mathrm{O}_{3}$ pollution levels in many urban areas. Brey and Fischer (2016) found that the mean $\mathrm{O}_{3}$ abundance measured on smoke-impacted days is higher than smoke-free days and the magnitude varies by location with a range of 3 to 36 ppbv. Furthermore, they found that the smoke-impacted $\mathrm{O}_{3}$ mixing ratios are most elevated in locations with the highest emissions of $\mathrm{NO}_{\mathrm{x}}$.

However, the $\mathrm{O}_{3}$ response can vary from significant to small enhancements and even depletion during different wildfire events (Val Martín et al., 2006). Buysse et al. (2019) and McClure \& Jaffe (2018) also report that maximum daily $8 \mathrm{~h}$ 
averaged (MDA8) $\mathrm{O}_{3}$ tends to decrease during heavy smoke influenced period when $\mathrm{PM}_{2.5}$ (particulate matter with diameters that are smaller than $2.5 \mu \mathrm{m}$ ) exceeds $70 \mu \mathrm{g} / \mathrm{m}^{3}$. The reasons for this are not fully understood but may be explained by some of the following conjectures in the literature. Alvarado et al. (2010) found that on average $40 \%$ of the $\mathrm{NO}_{\mathrm{x}}$ was converted to peroxyacetyl nitrate (PAN) within 1-2 hours after emission, thus limiting $\mathrm{NO}_{x}$ availability and in-situ $\mathrm{O}_{3}$ production. The potential loss of $\mathrm{O}_{3}$ due to reaction with organic carbon could decrease $\mathrm{O}_{3}$ concentrations in wildfire plumes. For example, de Gouw and Lovejoy (1998) found that heterogeneous reaction between $\mathrm{O}_{3}$ and organic aerosol can be an important loss for tropospheric $\mathrm{O}_{3}$, particularly if the aerosols contain unsaturated organic material. Fischer et al. (2010) found $\mathrm{O}_{3}$ enhancements of about $20 \mathrm{ppb}$ at a site downwind of a wildfire and estimated that about $8 \mathrm{ppb}$ could be attributed to the decomposition of PAN during adiabatic warming during subsidence. Moreover, Buysee et al. (2019) found lower $\mathrm{NO} / \mathrm{NO}_{2}$ ratios when sites are influenced by wildfire smoke and suggested several potential reasons including elevated atmospheric oxidants $\left(\mathrm{O}_{3}, \mathrm{RO}_{2}\right.$ and $\left.\mathrm{HO}_{2}\right)$, higher temperature, lower rates of $\mathrm{NO}_{2}$ photolysis due to shading, and increased interference in the $\mathrm{NO}_{2}$ measurements by other nitrogen species present in the wildfire smoke. A recent modeling study investigating a 2013 California wildfire showed that the simulation of near-fire smoke plume transport appears to perform well compared to satellite and aircraft measurements (Baker et al., 2018). While the photolysis rates in that study were also found to be wellcharacterized by the model, the predicted $\mathrm{O}_{3}$, on the other hand, did not compare well with either surface site nor aircraft measurements: $\mathrm{O}_{3}$ was overestimated by the model both aloft and at the surface during periods impacted by wildfires anywhere from 5 to over $50 \mathrm{ppb}$.

As alluded to already, the vast amounts of absorbing aerosols like brown and black carbon emitted from biomass burning could also influence the amount of radiation that reaches the surface. Airborne studies using aerosol and radiation measurements indicate that a layer of high aerosol loading lying below a temperature inversion could drastically reduce the downwelling solar and UV irradiance, including the surface $j\left(\mathrm{NO}_{2}\right)$ (Wendisch et al., 1996). Baylon et al. (2018) conducted an investigation of wildfire impacts on $\mathrm{O}_{3}$ production at a high elevation site located on Mt. Bachelor in Oregon, and report $j\left(\mathrm{NO}_{2}\right)$ decreasing by 14 to $21 \%$ at high solar zenith angles when biomass burning plumes were detected, but slightly increasing $(0.2 \sim 1.8 \%)$ at local noon. Furthermore, meteorological factors that may be correlated with wildfires and the conditions that lead to their proliferation such as temperature and humidity, could potentially affect the reactions associated with $\mathrm{O}_{3}$ production (Lin et al., 2017; Zhang et al., 2014). One study of the temperature dependence of $\mathrm{O}_{3}$ production in the San Joaquin Valley (SJV) (Pusede et al., 2014), for instance, found that the reactivity of total VOCs with $\mathrm{OH}\left(\mathrm{s}^{-1}\right)$ and the $\mathrm{HO}_{\mathrm{x}}$ production rate $\left(\mathrm{PHO}_{\mathrm{x}} \mathrm{ppts}^{-1}\right)$ both increased exponentially with temperature, leading to higher midday $\mathrm{O}_{3}$ concentrations by $1.5-2.0 \mathrm{ppb} / \mathrm{K}$. Steiner et al. (2010) also reported similar temperature dependencies on maximum $1 \mathrm{hr}$ ozone levels while underscoring their decreasing trend over the 25 years of their study, assumed to be a consequence of reducing $\mathrm{NO}_{\mathrm{x}}$ and $\mathrm{VOC}$ emissions across the state.

In the United States, the current National Ambient Air Quality Standards (NAAQS) for ozone is an MDA8 value equal to or exceeding $70 \mathrm{ppb}$. According to the California Air Resource Board (CARB), $\mathrm{O}_{3}$ concentrations frequently exceed existing

90 health-protective standard in metropolitan areas of California during summertime. In addition, the southern part of California's Central Valley (CV), the San Joaquin Valley (SJV), is still one of the two extreme $\mathrm{O}_{3}$ nonattainment areas remaining in the U.S. (U.S. EPA Green Book, www.epa.gov/green-book). With the projection of an increasing likelihood of large wildfires in the future across the western U.S. (Brey et al., 2021; Stavros et al., 2014), it is important to understand how 
$\mathrm{O}_{3}$ production will change subject to the rising influence of wildfire events in the $\mathrm{CV}$, and it will also be useful for the regulator to predict air quality degradation in the case of wildfire events.

In addition to the impacts of wildfires on air quality, Pahlow et al. (2005) present a proposed phenomenon that the shading effect of wildfire smoke can reduce the solar heating of the ground and lead to a shallower ABL, but the data evinced was only for three consecutive days on the US east coast. That study raises the question of whether the attenuation of $\mathrm{ABL}$ height due to wildfire shading is a general phenomenon and might it be supported by long-term observations. The strong correlation between downwelling surface solar radiation and ABL height has been described by previous studies. Pal and Haeffelin (2015) implemented a 5-year observational study of ABL height and surface fluxes near Paris in which they found the strongest determinant $(\mathrm{r}=0.92)$ of daily maximum $\mathrm{ABL}$ height was maximum downwelling shortwave radiation at the surface (SSWD), more so even than the surface heat flux ( $\mathrm{r}=0.5)$. The strong correlation between SSWD and afternoon ABL height was also verified by Trousdell et al. (2016) in the SJV with a similar dependence of $1.5-1.7 \mathrm{~m}_{\text {per }} \mathrm{Wm}^{-2}$. The lowest portion of the free troposphere (FT) in the SJV has a complex structure with a 'buffer layer' residing between ABL and FT, which is a layer of relatively stagnant air at altitudes between $500 \mathrm{~m}$ to $2500 \mathrm{~m}$ resulting from the onshore wind that impinges on the Southern Sierra Nevada mountains on the east side of the SJV (Faloona et al., 2020). This 'buffer layer' accumulates the pollutants from the ABL by anabatic sidewall venting during the daytime but continuously returns some of the air via midday entrainment, with turbulence within the ABL being the key factor that controls the entrainment process. If the shading effect of wildfire smoke can considerably influence the ABL dynamics or ABL height, then it will be important to quantify the amount of ABL height attenuation that results from wildfire smoke and elucidate the impacts on the ventilation of pollutants in the SJV because entrainment has a direct impact on surface level concentrations of most pollutants (Trousdell et al., 2019).

In this paper, we use data from $10 \mathrm{CARB}$ monitoring sites in the $\mathrm{CV}$ to quantify the impacts of wildfire smoke during summer (Jun-Sep) from 2016 to 2020. Then we use measured $\mathrm{O}_{3}, \mathrm{NO}$ and $\mathrm{NO}_{2}$ (corrected approximately for known interferences) in a modified Leighton relationship (Volz-Thomas et al., 2003) to estimate changes to the $\mathrm{O}_{3}$ production rate $\mathrm{P}\left(\mathrm{O}_{3}\right)$, accounting for the observed shading effect of the wildfire smoke on $j\left(\mathrm{NO}_{2}\right)$, as well as variations in ambient $\mathrm{O}_{3}$, and $k_{\mathrm{O}_{3}+N O}$ (rate constant in Eq. (R2)) due to temperature variations. In this way we are able to identify the specific impacts of wildfire emissions on regional ozone chemistry whereas past studies have tended to leave these impacts mingled together.

120 We also present the enhancement ratios (ERs) for $\mathrm{O}_{3} / \mathrm{T}, \mathrm{PM}_{2.5} / \mathrm{CO}$, and $\mathrm{O}_{3}$ production efficiency (OPE) during the wildfire influenced periods in the CV. Then, we discuss the influences of wildfire smoke on surface buoyancy and heat fluxes $\overline{\left(w^{\prime} \theta_{v}^{\prime}\right.}$, $Q_{H}$, and $Q_{E}$ ) measured by two AmeriFlux monitoring sites located in the northern part of the SJV. We also use a radio acoustic sounding system (RASS) located near Visalia to study wildfire impacts on temperature profiles and ABL heights. Our study aims at using long-term observation data to quantify the differences of $\mathrm{O}_{3}$ concentrations and production rates during the wildfire influenced periods in the $\mathrm{CV}$ and providing insights into the alteration of $\mathrm{ABL}$ dynamics that occurs in the presence of wildfire smoke. 


\section{Data and Methods}

\subsection{Measurements}

Measurements of hourly $\mathrm{PM}_{2.5}, \mathrm{O}_{3}$, nitric oxide (NO), nitrogen dioxide $\left(\mathrm{NO}_{2}\right)$, and $\mathrm{CO}$ are taken from $10 \mathrm{CARB}$ from airports nearest each air pollution monitoring site. Figure 2 shows a map (@ Google Earth 2020) for the locations of CARB sites as well as the RASS site and AmeriFlux sites used in our study. The locations and other detailed information about the sites can be found in Table 1. All the air pollution and meteorological data were download via the CARB website (https://www.arb.ca.gov/aqmis2/aqmis2.php), except for the data on reactive nitrogen compounds $\left(\mathrm{NO}_{\mathrm{y}}\right)$, which was downloaded via AirNow-Tech (http://www.airnowtech.org). The CARB gather air quality data for the State of California, ensures the quality of this data, designs, and implements air models, and sets ambient air quality standards for the state. The standard operating procedures for ambient air monitoring can be found on the CARB website (https://ww2.arb.ca.gov/resources/documents/standard-operating-procedures-ambient-air-monitoring). The hourly-averaged data start at the beginning of the reported time. Singular missing hourly measurements are replaced by the average of the hour

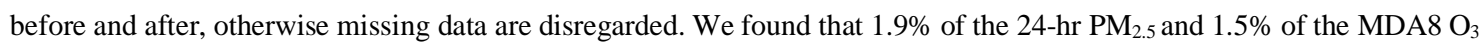
data are not available due to missing or erroneous values. We use temperature and relative humidity data from the CARB monitoring sites if they are available, otherwise we use measurements from meteorological sites at the nearest airport (Downloaded via AirNow-Tech, provided by Meteorological Assimilation Data Ingest system https://madisdata.ncep.noaa.gov (i.e., MADIS)). Since relative humidity is a function that strongly depends on temperature, we also calculate specific humidity (q) from pressure measurements at the airport and the Clausius-Clapeyron relationship to eliminate the direct dependence on temperature. Because approximately $80 \%$ of $\mathrm{O}_{3}$ exceedance days in the SJV typically occur between June 1 and September 30 (Trousdell et al., 2019), we focus on this period for each year (2016-2020). We calculate 24-hr $\mathrm{PM}_{2.5}$ and MDA8 $\mathrm{O}_{3}$ as daily metrics, and the average of other pollutant concentrations are from 10:00 and 15:00 Pacific Standard Time (PST) as daytime averages that are most relevant to peak ozone levels.

The conventional measurement of $\mathrm{NO}_{2}$ entails the catalytic conversion of $\mathrm{NO}_{2}$ to $\mathrm{NO}$ on a heated molybdenum (Mo) surface and subsequently measured by chemiluminescence after reaction with $\mathrm{O}_{3}$. The drawback of this method is that other oxidized nitrogen compounds such as PAN and $\mathrm{HNO}_{3}$ can also be converted to $\mathrm{NO}$, thus the molybdenum conversion method is known to cause overestimation of $\mathrm{NO}_{2}$. Steinbacher et al. (2007) proposed a correction method for overestimated $\mathrm{NO}_{2}$ measurements based on their long-term observations in rural Switzerland via Eq. (6): where $\Delta \mathrm{NO}_{2}$ is the amount of overestimation for $\mathrm{NO}_{2},\left(\mathrm{NO}_{2}\right)_{m}$ is the measured $\mathrm{NO}_{2}$ concentration, $\mathrm{O}_{3}$ is measured ozone concentration. a, b, c, d, e, and $f($ month) are constants, and $f($ day $)$ is binary predictor distinguishing day time and night time ( 1 or 0$)$, and $\varepsilon$ is a residual noise term that we ignored in our study. Details about those constants can be found in Table C1. All the $\mathrm{NO}_{2}$ measurements in this study are corrected according to Eq. (6), with the resultant $\mathrm{NO}_{2}$ decreasing on average by about $1.5 \mathrm{ppb}(\sim 30 \%)$ after the correction. This is not meant to perfectly eliminate all of the potential interferences in this measurement but is intended to eliminate the bulk of the interferences that are known to exist with this analytical technique. A similar analysis of the interference in the heated Mo technique, relative to a spectral $\mathrm{NO}_{2}$ measurement, was reported by Dunlea et al. (2007) in Mexico City, a very different environment, in which they found the long-term average to be $\sim 22 \%$ in 

this widespread chemiluminescence measurement.

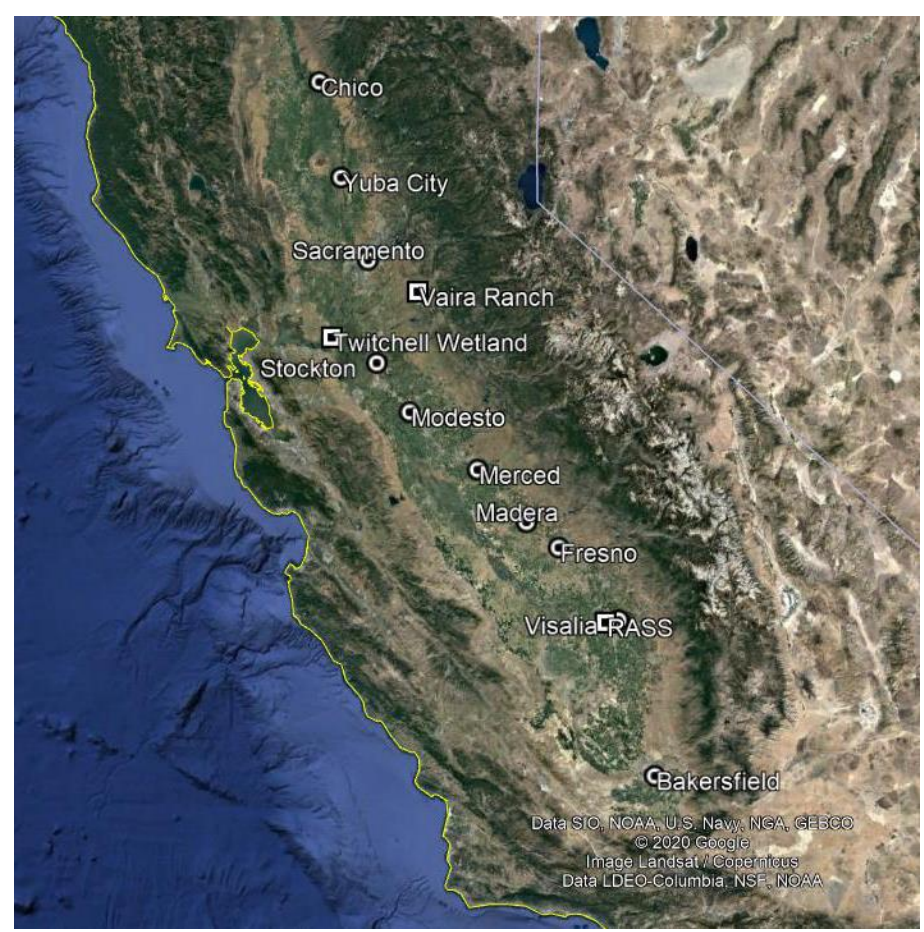

Figure 2: A map of the locations of CARB sites (circles), RASS site and AmeriFlux sites (squares) used in this study (C) Google Earth 2020).

Table 1: The locations of measurement sites and detailed information.

\begin{tabular}{|c|c|c|c|}
\hline Site Name & $\begin{array}{c}\text { Site Location } \\
\left({ }^{\circ} \mathrm{N},{ }^{\circ} \mathrm{E}\right)\end{array}$ & Agency & Measurements \\
\hline Chico-East & $39.76,-121.84$ & CARB & $\begin{array}{c}\mathrm{O}_{3}, \mathrm{PM}_{2.5}, \mathrm{CO}, \\
\mathrm{NO}, \mathrm{NO}_{2}, \mathrm{~T}, \mathrm{RH}\end{array}$ \\
\hline MADIS-KCIC & $39.80,-121.85$ & MADIS & U, RH (2016) \\
\hline Yuba City & $39.14,-121.62$ & CARB & $\begin{array}{c}\mathrm{O}_{3}, \mathrm{PM}_{2.5}, \mathrm{NO} \\
\mathrm{NO}_{2}, \mathrm{~T}, \mathrm{RH}\end{array}$ \\
\hline MADIS-KMYV & $39.10,-121.57$ & MADIS & $\begin{array}{c}\text { U, P, RH (2016- } \\
\text { 2017) }\end{array}$ \\
\hline Sutter Buttes & $39.21,-121.82$ & CARB & CO (2017-2019) \\
\hline $\begin{array}{l}\text { Arden Arcade - } \\
\text { Del Paso Manor }\end{array}$ & $38.61,-121.37$ & $\begin{array}{c}\text { Sacramento } \\
\text { Metro. AQMD }\end{array}$ & $\begin{array}{c}\mathrm{O}_{3}, \mathrm{PM}_{2.5}, \mathrm{CO} \\
(2016-2019), \mathrm{NO}, \\
\mathrm{NO}_{2}, \mathrm{~T}, \mathrm{RH}, \mathrm{U}, \mathrm{P}\end{array}$ \\
\hline
\end{tabular}




\begin{tabular}{|c|c|c|c|}
\hline $\begin{array}{c}\text { Stockton - } \\
\text { Hazelton Street }\end{array}$ & $37.95,-121.27$ & CARB & $\begin{array}{c}\mathrm{O}_{3}, \mathrm{PM}_{2.5}, \mathrm{CO} \\
\mathrm{NO}, \mathrm{NO}_{2}, \mathrm{~T}, \mathrm{RH}\end{array}$ \\
\hline MADIS-KSCK & $37.90,-121.25$ & MADIS & U, P, RH (2016) \\
\hline $\begin{array}{l}\text { Modesto - 14th } \\
\text { Street }\end{array}$ & $37.64,-120.99$ & CARB & $\begin{array}{c}\mathrm{O}_{3}, \mathrm{PM}_{2.5}, \mathrm{CO}, \mathrm{T} \\
\mathrm{RH}\end{array}$ \\
\hline $\begin{array}{l}\text { MADIS-KMOD } \\
\text { Merced - S. } \\
\text { Coffee Ave }\end{array}$ & $37.63,-120.95$ & $\begin{array}{l}\text { MADIS } \\
\text { CARB }\end{array}$ & $\begin{array}{l}\mathrm{U}, \mathrm{P}, \mathrm{RH}(2016) \\
\mathrm{O}_{3}, \mathrm{PM}_{2.5}, \mathrm{NO} \\
\mathrm{NO}_{2}, \mathrm{~T}, \mathrm{RH}, \mathrm{U}\end{array}$ \\
\hline Madera-City & $36.95,-120.03$ & $\begin{array}{c}\text { San Joaquin } \\
\text { Valley Unified } \\
\text { APCD }\end{array}$ & $\mathrm{P}, \mathrm{PM}_{2.5}$ \\
\hline $\begin{array}{c}\text { Madera - Pump } \\
\text { Yard }\end{array}$ & $36.87,-120.01$ & $\begin{array}{c}\text { San Joaquin } \\
\text { Valley Unified } \\
\text { APCD }\end{array}$ & $\begin{array}{c}\mathrm{O}_{3}, \mathrm{CO}, \mathrm{NO}, \\
\mathrm{NO}_{2}, \mathrm{~T}, \mathrm{RH}, \mathrm{U}\end{array}$ \\
\hline Fresno - Garland & $36.79,-119.77$ & CARB & $\begin{array}{c}\mathrm{O}_{3}, \mathrm{PM}_{2.5}, \mathrm{CO} \\
\mathrm{NO}, \mathrm{NO}_{2}, \mathrm{~T}, \mathrm{RH}\end{array}$ \\
\hline MADIS-KFAT & $36.77,-119.72$ & MADIS & U, P, RH (2016) \\
\hline $\begin{array}{l}\text { Visalia - N. } \\
\text { Church Street }\end{array}$ & $36.33,-119.29$ & CARB & $\begin{array}{c}\mathrm{O}_{3}, \mathrm{PM}_{2.5}, \mathrm{NO} \\
\mathrm{NO}_{2}, \mathrm{~T}, \mathrm{RH}\end{array}$ \\
\hline MADIS-KVIS & $36.32,-119.40$ & MADIS & U, P, RH (2016) \\
\hline $\begin{array}{l}\text { Bakersfield - } \\
\text { California Ave }\end{array}$ & $35.36,-119.06$ & CARB & $\mathrm{PM}_{2.5}$ \\
\hline $\begin{array}{l}\text { Bakersfield- } \\
\text { Muni }\end{array}$ & $35.33,-119.00$ & $\begin{array}{c}\text { San Joaquin } \\
\text { Valley Unified } \\
\text { APCD }\end{array}$ & $\begin{array}{c}\mathrm{O}_{3}, \mathrm{CO}, \mathrm{NO}, \\
\mathrm{NO}_{2}, \mathrm{~T}, \mathrm{RH}, \mathrm{U}, \mathrm{P}\end{array}$ \\
\hline
\end{tabular}

\subsection{Wildfire identification}

We use the NOAA Hazard Mapping System (HMS) Fire and Smoke Product and the Hybrid Single Particle Lagrangian Integrated Trajectory (HYSPLIT) model accessed from AirNow-Tech (https://www.airnowtech.org/index.cfm) as an identification tool for wildfire events. The HMS is an interactive environmental satellite image display and graphical system that was developed by National Environmental Satellite, Data, and Information Service. The HMS is used by trained satellite analysts to generate a daily operational list of fire locations and outline areas of smoke (Brey et al., 2018). The analysts also rely primarily on visible satellite images to confirm that the fire locations are actually producing smoke. Then these detected points of fire locations are used to initiate the HYSPLIT model by NOAA, which is a complete system for computing simple air parcel trajectories, as well as complex transport, dispersion, chemical transformation, and deposition simulations (Stein et al., 2015), to estimate the movement of smoke in the NWS (National Weather Service) smoke forecast (Rolph et al., 2009; 
Ruminski et al., 2006). The HMS creates a fresh map for North America daily around 7-8 a.m. Eastern time. For the performance time of the HMS in the CV (4-5 a.m. PST), this may cause a situation wherein the site is not detected by HMS with overhead smoke early in the morning but could be covered by smoke the rest of the day. In addition, because the HMS system is a satellite-based product, it is observed from above, therefore it cannot differentiate surface wildfire plumes from lofted plumes and may also be limited by any cloud cover. These limitations may cause improper identification of wildfire events; therefore, we use additional methods to verify the presence of wildfire smoke at the surface level. Thus, we also use the HYSPLIT model to analyze the back-trajectories of the air parcels starting at each target site and trace its origin at surface level and within the ABL. By using the HMS and HYSPLIT, the steps for wildfire identification are as follows. First, we use the HMS product to see if any sites are covered by smoke. The target sites that are covered by the HMS smoke are marked according to the category of the HMS product as thin, medium, and thick smoke coverage. Second, we use the HYSPLIT model to calculate 24-hour back-trajectories at 12:00 p.m. PST starting from the sites that are covered with the HMS wildfire smoke areas. The HYSPLIT model is performed at altitudes of $100 \mathrm{~m}, 600 \mathrm{~m}$ and $1500 \mathrm{~m}$, respectively, with a resolution of $12 \mathrm{~km}$ (NAM 12km), which will provide the transport pattern near the surface, the top of boundary layer and in the middle of the "buffer layer" (Faloona et al., 2020) or what is sometimes called the "stable core layer" (Leukauf et al., 2016) of a valley atmosphere. Given that the low-level flow in the CV has a well-characterized diurnal pattern during summertime (Zhong et al., 2004), we think that the HYSPLIT back-trajectory performed at 3 different levels are enough to represent the transport pattern of the air flow near the surface during our periods of study. If the HMS shows overhead smoke coverage and one of the HYSPLIT back-trajectories originated from or passed by the area of fire spots detected by the HMS, we define the target site as influenced by wildfire smoke on that day. The purpose of our method involving both the HMS system and the HYSPLIT model is to identify cases that contain a significant impact of wildfire smoke at the surface level as accurately as possible. We believe that even if the fire plume is overhead and the back-trajectory ends above the ABL, strong daytime subsidence and entrainment over the valley will likely bring the wildfire effluent into the ABL and affect surface concentrations of air pollutants. Moreover, we also need a baseline to provide the conditions (e.g., pollutant concentrations, ABL height) without the influences of wildfire smoke to use as a control sample. We use images from the true color reflectance of MODIS Aqua and Terra to identify the days that are without cloud coverage and immediately before and after the wildfire influenced periods as our baseline. In the following paragraphs, we will refer to those as the background or nonfire days. In this way, we are able to identify the wildfire events at each site and then use the baseline from background days to compare with the cases when the wildfire smoke is present at surface level.

\section{$2.3 \mathrm{O}_{3}$ production}

The modified Leighton relationship is a method to determine the relative magnitude of the in-situ photochemical $\mathrm{O}_{3}$ production rate by measuring the extent to which the $\mathrm{O}_{3}-\mathrm{NO}_{x}$ cycle is away from the photostationary state. This method represents the photochemical cycle of $\mathrm{O}_{3}, \mathrm{NO}_{\mathrm{x}}, \mathrm{HO}_{2}$ and $\mathrm{RO}_{2}$ (Leighton, 1961). The chemical reactions entailed in this cycle are in Eq. (R1)-Eq. (R4), where $j\left(\mathrm{NO}_{2}\right)$ is the photolysis rate in Eq. (R1), $k_{\mathrm{O}_{3}}, k_{\mathrm{HO}_{2}}$ and $k_{\mathrm{RO}_{2}}$ are reaction rate coefficients for Eq. (R2), (R3) and (R4), respectively. The role of wildfire smoke will include the addition of $\mathrm{NO}_{\mathrm{x}}$ and VOCs, which results in changing the concentration of $\mathrm{HO}_{2}, \mathrm{RO}_{2}, \mathrm{NO}_{\mathrm{x}}$ and their ensuing effects on $\mathrm{O}_{3}$ production.

$\frac{[\mathrm{NO}]}{\left[\mathrm{NO}_{2}\right]}=\frac{j\left(\mathrm{NO}_{2}\right)}{k_{\mathrm{O}_{3}}\left[\mathrm{O}_{3}\right]+k_{\mathrm{HO}_{2}}\left[\mathrm{HO}_{2}\right]+k_{\mathrm{RO}_{2}}\left[\mathrm{RO}_{2}\right]}$ 
The $\mathrm{O}_{3}$ production rate is derived from the modified Leighton relationship presented in Eq. (7). Equation (R3) and (R4) determine the limiting rates for $\mathrm{O}_{3}$ production, thus the production rate of $\mathrm{NO}_{2}$ in Eq. (R3) and (R4) is the effective production rate for 'new' $\mathrm{O}_{3}$ that does not belong to the instantaneous photostationary state cycle. This can be expressed as:

where $[\mathrm{NO}],\left[\mathrm{NO}_{2}\right]$ and $\left[\mathrm{O}_{3}\right]$ are hourly averaged mixing ratio measured by $\mathrm{CARB}$, and $k_{\mathrm{HO}_{2}}\left[\mathrm{HO}_{2}\right]+k_{\mathrm{RO}_{2}}\left[\mathrm{RO}_{2}\right]$ represent the contributions of VOC (and $\mathrm{CO}$ ) in $\mathrm{O}_{3}$ production. The direct measurements of $j\left(\mathrm{NO}_{2}\right)$ at ground level are not often available in field studies. Trebs et al. (2009) reported a relationship that can be used to estimate ground-level $j\left(\mathrm{NO}_{2}\right)$ directly from the solar irradiance, which is measured as a standard parameter in most field measurements. In the absence of direct measurement of $j\left(\mathrm{NO}_{2}\right)$, this method is more reliable than radiative transfer calculations with poorly known input parameters. We use surface solar radiation measurements from California Irrigation Management Information System (CIMIS, https://cimis.water.ca.gov/WSNReportCriteria.aspx) to calculate the hourly $j\left(\mathrm{NO}_{2}\right)$ by using a second-order polynomial function (A1) in Trebs et al. (2009) study. This approach is employed to account for the decreased photolysis rates during wildfire events due to the shading effect of the overhead smoke. Moreover, $k_{\mathrm{O}_{3}}$ is also adjusted to corresponding hourlyaveraged temperature measured at each site to account for the changes of rate coefficients due to temperature change using Eq. (A2) (Lippmann et al., 1980).

The concentration of $\mathrm{HO}_{2}$ and $\mathrm{RO}_{2}$ is estimated from Eq. (8) and we consider the sum of $\mathrm{HO}_{2}$ and $\mathrm{RO}_{2}$ as $\mathrm{RO}_{\mathrm{x}}$. The rate constants for Eq. (R5) and (R6) are within $\sim 5 \%$ at $310 \mathrm{~K}$ (Brasseur et al., 1999), so we assume they are equal and solve for total $\mathrm{RO}_{\mathrm{x}}$, the results are presented as the effective first-order reaction rate $\mathrm{k}\left[\mathrm{RO}_{\mathrm{x}}\right]\left(\mathrm{s}^{-1}\right)$. Although $\mathrm{HO}_{2}+\mathrm{RO}_{2}$ tends to be overestimated by using this method (Griffin et al., 2007; Mannschreck et al., 2002; Volz-Thomas et al., 2003), we still consider it useful when comparing the relative differences between wildfire-influenced and background periods in order to investigate the impact of additional $\mathrm{RO}_{\mathrm{x}}$ or VOC, distinct from changes in $\mathrm{NO}$ and $j\left(\mathrm{NO}_{2}\right)$ on the overall in-situ photochemical $\mathrm{O}_{3}$ production rates.

\subsection{Boundary layer dynamics}

We use surface eddy covariance flux data from two AmeriFlux sites located at Twitchell Wetland (Knox et al., 2018) (38.1074 N, 121.6469 W, -5m) and Vaira Ranch (Ma et al., 2021) (38.4133 N, 120.9507 W, 129m). The Twitchell site has a flux tower equipped to analyze energy, $\mathrm{H}_{2} \mathrm{O}, \mathrm{CO}_{2}$, and $\mathrm{CH}_{4}$ fluxes since May 2012, which is located at a 7.4-acre restored wetland on Twitchell Island. The wetland is almost completely covered by cattails and tules by the third growing season. Vaira Ranch site has been established at the lower foothills of the Sierra Nevada mountains on privately owned land since 2000; the site is classified as a grassland dominated by C3 annual grasses. The measurements at the two sites include surface sensible heat flux $\left(Q_{H}\right)$, latent heat flux $\left(Q_{E}\right)$, temperature, incoming shortwave radiation, and the mole fraction of water vapor. The time resolution is 30 minutes, and the measurements are available from 2016 to 2019. The surface buoyancy flux is calculated by Eq. (9), where $\bar{\theta}, \overline{w^{\prime} \theta^{\prime}}$ and $\overline{w^{\prime} q^{\prime}}$ are direct measurement from the site, and $\bar{q}$ is calculated from the measured mole fraction of water vapor.

We use the same wildfire events identification results from section 2.2 to categorize wildfire days and background days, where Twitchell Island (30km northwest of Stockton) uses the results of Stockton and Vaira Ranch (50 km southeast of 
Sacramento) uses the result of Sacramento. Then, we calculate the averaged diurnal profile for $\overline{w^{\prime} \theta_{v}^{\prime}}, Q_{H}, Q_{E}$, and incoming shortwave radiation for wildfire-influenced and background days at each site.

Radio acoustic sounding systems (RASS) remotely measure the virtual temperature and wind profile up to about $2 \mathrm{~km}$, and their 1-hour time resolution has substantial advantages over radiosondes. We use the virtual temperature data measured by the RASS located near the Visalia Municipal Airport. Then, the virtual temperature is converted into virtual potential temperature by the hypsometric and Poisson's equations based on the surface measurements of temperature and pressure. The ABL height is estimated by the first range gate where the vertical virtual potential temperature gradient exceeds $10 \mathrm{~K} / \mathrm{km}$. Then, the estimated ABL heights are also sorted into wildfire influenced days and background days for comparison. A 5-year monthly averaged diurnal ABL height profile retrieved by this method during June to September, 2016-2020 is shown in Fig. B4. The magnitude and timing of the ABL heights correspond approximately to the diurnal ABL profiles in the SJV measured by Bianco et al. (2011) and Faloona et al. (2020).

\section{Results and Discussion}

\subsection{Summary of wildfire events from 2016 to 2020}

During the summer time (June to September) in the CV, wildfires are prone to happen amidst the mountains that surround the valley and spread upslope in general. The yearly acres burned by wildfire in California during the study ranges from 259,148 in 2019 to 1,823,153 in 2018 (National Interagency Coordination Center, https://www.nifc.gov/fireInfo/fireInfo_statistics.html). By September 2020, the 2020 fire season in California had become the most intense year of the 18-year long fire radiative power measurements collected by satellite (NOAA/NESDIS Hazard Mapping System, https://www.ospo.noaa.gov/Products/land/hms.html). The number of wildfire-influenced days at each site are in Table C2. Although the wildfire-influenced days vary from site to site, the average total number of the wildfire days are about 120 days out of 600 days ( 20\%) from our 5-year data analysis (2016-2020).

We summarize the characteristic value of daily maximum temperature $\left(\mathrm{T}_{\max }\right)$, relative humidity $(\mathrm{RH})$, specific humidity (q), scalar-mean windspeed (U), 24-hr $\mathrm{PM}_{2.5}, \mathrm{MDA} 8 \mathrm{O}_{3}, \mathrm{CO}$ and $\mathrm{NO}_{\mathrm{x}}$ for wildfire and background days at each site in Fig. 3. The error bars show the interquartile range limited by $25^{\text {th }}$ and $75^{\text {th }}$ percentiles, and the center mark denotes the median value. For 24-hr $\mathrm{PM}_{2.5}$ and $\mathrm{CO}$, concentrations on wildfire days are significantly higher than non-fire days at all sites, since fine particles and $\mathrm{CO}$ are major products of biomass burning and are also good tracers of wildfire smoke. On average, the 24-hr $\mathrm{PM}_{2.5}$ and $\mathrm{CO}$ are $8.7 \mu \mathrm{g} / \mathrm{m}^{3}(\sim 102 \%)$ and $76 \mathrm{ppb}(\sim 48 \%)$ higher than background periods, respectively. For most sites, the $25^{\text {th }}$ percentile of the wildfire value is higher than the $75^{\text {th }}$ percentile of non-fire periods. The clear difference in the concentrations of $\mathrm{PM}_{2.5}$ and $\mathrm{CO}$ between wildfire and background days suggest that our wildfire identification method using the HMS system in conjunction with the HYSPLIT back-trajectory model can appropriately detect the presence of wildfire smoke at surface levels. It also suggests that our identification method has a similar effectiveness compared to methods that use the HMS system and background $\mathrm{PM}_{2.5}$ or $\mathrm{CO}$ as a threshold (e.g., mean background values plus one standard deviation) for wildfire identification in previous studies (McClure et al., 2018; Briggs et al.,2016). The $\mathrm{MDA}_{8} \mathrm{O}_{3}$ and $\mathrm{NO}_{\mathrm{x}}$ concentrations are also enhanced during fire days by $6.5 \mathrm{ppb}(\sim 12 \%)$ and $0.9 \mathrm{ppb}(\sim 35 \%)$ on average. The histograms in Fig. B1 show that about $28 \%$ of the wildfire-influenced days exceed the NAAQS of 70 ppb MDA8 $\mathrm{O}_{3}$ versus only $12 \%$ during 
background periods. The numbers and percentages of $\mathrm{MDA} 8 \mathrm{O}_{3}$ exceedances of $70 \mathrm{ppb}$ at each site are presented in Table C4. Overall, the wildfire events contribute to about $44 \%$ of the total exceedance cases. Using a global chemical transport model Pfister et al. (2008) estimated that the $\mathrm{MDA}_{8} \mathrm{O}_{3}$ increased by about $10 \mathrm{ppb}$ on average for all sites in California during the wildfire events in the Fall (September to December) of 2007. Note that our study focuses only on the CV region in the summer months a decade later when the ambient $\mathrm{NO}_{2}$ levels have decreased by approximately $50 \%$ in large urban areas (Simon et al., 2015) in California, and the model of Pfister et al. (2008) exhibits biases in MDA8 $\mathrm{O}_{3}$ of 10-15 ppb in fire and background conditions. Moreover, Figure 3 shows that the MDA8 $\mathrm{O}_{3}$ has a southward directed gradient, in general, with higher $\mathrm{O}_{3}$ concentration in the SJV than in the SV independent of whether or not wildfire emissions are present. This result is consistent with the EPA Green Book and the study conducted by Trousdell et al. (2019), in which they find that $\mathrm{O}_{3}$ pollution in the SJV is still a problematic issue.
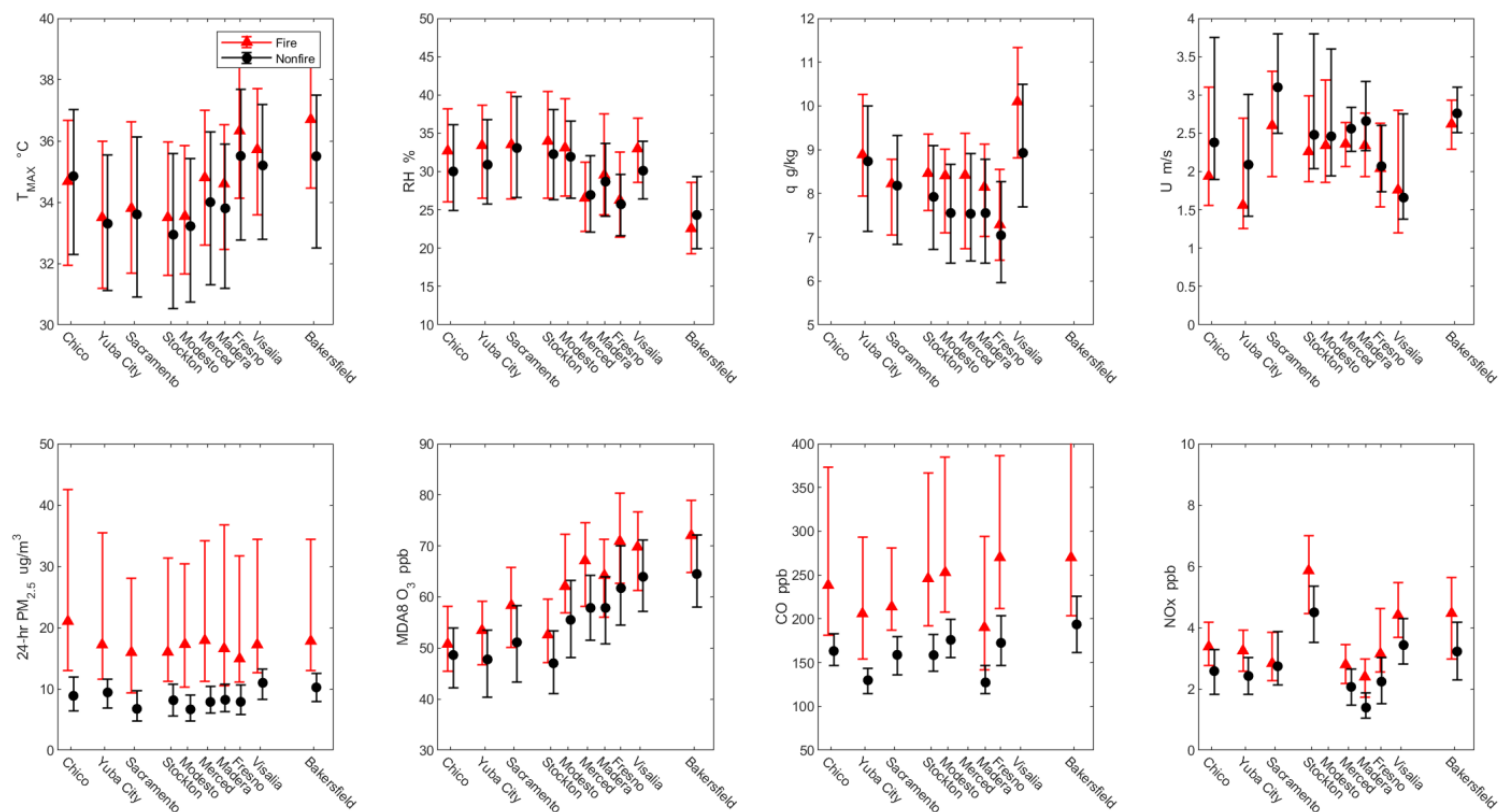

Figure 3: Median values for fire (red triangle) and non-fire (black circle) periods at each station, error bars represent $25^{\text {th }}$ and $75^{\text {th }}$ percentile values. $\mathrm{RH}, \mathrm{q}, \mathrm{U}, \mathrm{CO}$ and $\mathrm{NO}_{\mathrm{x}}$ are 5-hour averaged values between 10:00 to 15:00 PST. The interval of station-axis labeling is scaled to the latitude of each site.

For meteorological factors, all sites except Chico show a higher median value ( $\sim 0.5 \mathrm{~K}$ on average) of $\mathrm{T}_{\max }$ on wildfire influenced days. The result of higher temperature matches the previous long-term climatology studies on wildfire in U.S. from 1971 through 1984 (Potter, 1996), in which they report that wildfire events correspond to positive temperature anomalies. Brey et al. (2018) also show that in Mediterranean California, the temperature is positively correlated with human-ignited burn area and the precipitation and RH are negatively correlated with both of human-ignited and lightningignited area, though the Pearson correlations are relatively smaller in California than other regions. The study of Brey et al. (2021) found that in California's mountain regions, using wind speed, RH, and vapor pressure deficit (VPD) as the predictors of wildfire burn areas yield ubiquitously small coefficients, and that only when RH is excluded as a predictor does the 
coefficient for summer VPD become appreciable in both historical data and future projections. However, in our study, a consistently higher specific humidity (q) is observed at all sites during wildfire periods by $0.6 \mathrm{~g} / \mathrm{kg}$ on average. Additionally, higher RH values are also detected at most sites except for Merced and Bakersfield. The higher water vapor content observed in the valley ABL during wildfire periods is most likely not attributable to the chemical product of fuel combustion in the wildfires because that contribution would be stoichiometrically similar to $\mathrm{CO}_{2}$ which is only observed to be enhanced by order of $\sim 10$ ppmv in such environments (Langford et al., 2020). Furthermore, the surface wind speeds show a reduction of about $0.3 \mathrm{~m} / \mathrm{s}$ on average during wildfire periods at most sites except for Madera and Fresno. Thus, we hypothesize that the higher water vapor content and lower wind speeds are the result of weaker ABL entrainment due to the shading effect from wildfire plumes because of the reduced surface heat fluxes. This will be discussed further in section 3.3.

We note that the $\mathrm{O}_{3}$ concentrations have a relatively strong correlation with ambient temperature (Fig. B2) thus this meteorological variation needs to be considered when we analyze the $\mathrm{O}_{3}$ enhancement (i.e., enhancement ratios for $\mathrm{O}_{3}$ and temperature). According to Pusede et al., 2014, a study of daily maximum temperature versus daytime (10:00-14:00 local time) $\mathrm{O}_{3}$ concentrations in Bakersfield, CA show the change of $\mathrm{O}_{3}$ concentration with respect to temperature variation $\left(\Delta \mathrm{O}_{3} / \Delta \mathrm{T}_{\max }\right)$ to be around $2 \mathrm{ppb} / \mathrm{K}$. Steiner et al. (2010) report $\mathrm{O}_{3}$-temperature slopes of $2.4 \mathrm{ppb} / \mathrm{K}$ and $1.8 \mathrm{ppb} / \mathrm{K}$ in $\mathrm{SJV}$ and $\mathrm{SV}$, respectively, yet their data is already a decade old, and they found that these slopes had been decreasing over the 30 years of their study. Our study (Fig. B2) shows that $\Delta \mathrm{O}_{3} / \Delta \mathrm{T}_{\max }$ is on average $1.7 \mathrm{ppb} / \mathrm{K}$ for the background periods in the SJV and $1.3 \mathrm{ppb} / \mathrm{K}$ in the $\mathrm{SV}$, consistent with a continued decrease in this parameter over time. Moreover, we found that the average slopes increase in the presence of wildfire emissions to $2.2 \mathrm{ppb} / \mathrm{k}(\mathrm{SJV})$ and $1.6 \mathrm{ppb} / \mathrm{K}$ (SV) also consistent with its dependence on precursor emissions (Sillman \& Sampson, 1995). Thus, with an average of $0.5 \mathrm{~K}$ increase in temperature $\left(\mathrm{T}_{\max }\right)$, we expect that approximately $1 \mathrm{ppb}$ of the observed $\mathrm{O}_{3}$ enhancement is due to the temperature increment during wildfire periods and the rest, $5.5 \mathrm{ppb}$ of $\mathrm{O}_{3}$ enhancement, is due to the influences of wildfire smoke. We also found that the ERs for $\Delta \mathrm{PM}_{2.5} / \Delta \mathrm{CO}$ have a strong positive correlation at all ten sites (Fig. B3), indicating that the $\mathrm{PM}_{2.5}$ and $\mathrm{CO}$ are well connected to wildfire influence. Our average ER for $\Delta \mathrm{PM}_{2.5} / \Delta \mathrm{CO}$ (m value in Fig. B3) is $0.12( \pm 0.03) \mu \mathrm{g} / \mathrm{m}^{3} \mathrm{ppb}^{-1}$, which agrees well with the value (0.107) found by Selimovic et al. (2019) in a study from two summers in Missoula, Montana as well as the value (0.12) reported by McClure and Jaffe (2018) from wildfires in Idaho.

\subsection{Wildfire smoke influences on $\mathrm{PM}$ and $\mathrm{O}_{3}$ production}

In order to investigate the $\mathrm{O}_{3}$ variations and their relationship to the existence of additional PM from wildfire smoke, we plot the binned 24-hr $\mathrm{PM}_{2.5}$ versus corresponding $\mathrm{MDA}_{8} \mathrm{O}_{3}$ in Fig. 4. Since $\mathrm{O}_{3}$ enhancements react differently across the CV, we separate our sites into two geographical categories: Chico, Yuba City and Sacramento into Sacramento Valley (SV) (Fig. 4(b)) and the remaining sites to the south into the SJV (Fig. 4(c)). Generally, MDA8 O increases with PM at low 24-hr PM2.5 concentrations for both the wildfire and background periods, peaking around 40 to $55 \mu \mathrm{g} / \mathrm{m}^{3}$, then becomes independent of $\mathrm{PM}$ at higher concentration $\left(\mathrm{PM}_{2.5}>55 \mu \mathrm{g} / \mathrm{m}^{3}\right.$ ). The slopes of the $\mathrm{O}_{3}$ to $\mathrm{PM}_{2.5}$ relationship (below $40 \mu \mathrm{g} / \mathrm{m}^{3}$ ) are higher in the

340 SJV than the SV. The non-linear relationship in our results generally aligns with the results from previous studies (Buysse et al.,2019; McClure et al., 2018), in which an increase of $\mathrm{MDA}_{8} \mathrm{O}_{3}$ with PM is found at low to moderate PM with a peak of MDA8 $\mathrm{O}_{3}$ around 40 to $55 \mu \mathrm{g} / \mathrm{m}^{3}$. However, our results do not show a clear decreasing trend of MDA8 $\mathrm{O}_{3}$ at higher PM. The MDA8 $\mathrm{O}_{3}$ did slightly decrease when $\mathrm{PM}_{2.5}$ exceed $55 \mu \mathrm{g} / \mathrm{m}^{3}$ in SJV, but it returns to its peak value when $\mathrm{PM}_{2.5}>100 \mu \mathrm{g} / \mathrm{m}^{3}$. 

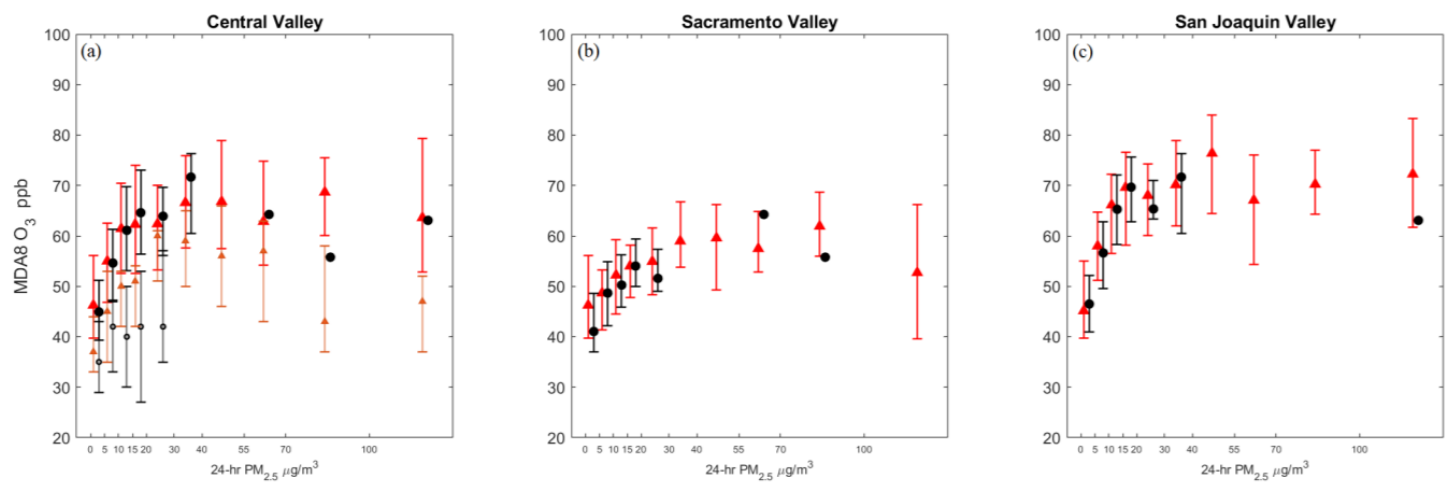

Figure 4: Plots for binned 24-hr $\mathrm{PM}_{2.5}$ versus MDA8 $\mathrm{O}_{3}$ for all ten sites (a); Chico, Yuba City, and Sacramento are in (b); and

Error bars denote $25^{\text {th }}$ and $75^{\text {th }}$ percentile values. The number of datapoints in each bin can be found in Table C3. The orange (fire) and grey (non-fire) error bars are the result from Buysee et al. (2019) for comparison.

The $\mathrm{O}_{3}$ production rate $\left(\mathrm{PO}_{3}\right)$, the effective first-order reaction rate $\mathrm{k}\left[\mathrm{RO}_{\mathrm{X}}\right]\left(\mathrm{s}^{-1}\right), \mathrm{NO}$, and the attenuation of incoming solar radiation are shown separately in Fig. 5. The peak value of solar radiation (Fig. 5(d)) decreases by $7 \%$ on average at all ten sites during the wildfire periods. The $\mathrm{PO}_{3}$ (Fig. 5(c)) that is calculated from the modified Leighton ratio increases at all sites during the wildfire influenced periods. Despite the diminution of $j\left(\mathrm{NO}_{2}\right)$ due to the shading effect of wildfire smoke, the $\mathrm{PO}_{3}$ increases by $26 \%$ (average of each site's enhancement ratio.) The rate $\mathrm{k}\left[\mathrm{RO} \mathrm{X}_{\mathrm{X}}\right]\left(\mathrm{s}^{-1}\right)$ (Fig. 5(b)) does not show a consistent enhancement pattern among all ten sites, but overall is enhanced by $11 \%$. Figure 5(a) shows the NO concentrations are on average $0.07 \mathrm{ppb}(19 \%)$ higher during wildfire periods, though two sites show negative increments. However, despite the variances of $\mathrm{NO}$ and $\mathrm{k}\left[\mathrm{RO}_{\mathrm{X}}\right]$ at different sites, all sites have an enhancement of in-situ $\mathrm{PO}_{3}$, which implies that the role of wildfire smoke is to provide additional $\mathrm{NO}, \mathrm{RO}_{2}$ and $\mathrm{HO}_{2}$ to the $\mathrm{O}_{3}$ photochemical cycle. The $\mathrm{PO}_{3}$ and $\mathrm{k}\left[\mathrm{RO} \mathrm{X}_{\mathrm{X}}\right]$ that are estimated from the modified Leighton ratio in our study tend to be higher than measured or modeled values (Pusede et al., 2014; Tan et al., 2018). Volz-Thomas et al. (2003) also used a modified Leighton ratio to estimate $\mathrm{PO}_{3}$ and their results yielded up to $90 \mathrm{ppb} / \mathrm{h}$, which is similar to the magnitude of our results. They also calculate $\mathrm{PO}_{3}$ from measured peroxy radicals and the result was much lower, around $10 \mathrm{ppb} / \mathrm{h}$. There is a well-established record of the modified Leighton ratio method leading to significant overprediction of $\mathrm{RO}_{2}+\mathrm{HO}_{2}$ levels and thus implied photochemical ozone production rates (Volz-Thomas et al., 2003; Mannschreck et al., 2004; Griffin et al., 2007; Trousdell et al., 2019) for reasons that are not understood. We therefore do not expect this method to be accurate in this study, but we do believe that the results are still instructive in analyzing the relative changes in $\mathrm{P}\left(\mathrm{O}_{3}\right)$ and $\left[\mathrm{HO}_{2}\right]+\left[\mathrm{RO}_{2}\right]$ during wildfire and background periods. Overall, the relative increases in $\left.\mathrm{P}_{3} \mathrm{O}_{3}\right)$ of $\sim 26 \%$ during wildfire periods imply that $\mathrm{O}_{3}$ enhancements are due to both increased peroxy radicals (or VOC precursors) and NO in approximately equal measure (11\% and 19\% increases respectively.) Although at some sites $\mathrm{NO}$ enhancements overwhelmed a dip in $\mathrm{RO}_{\mathrm{x}}$ (Madera \& Visalia), and at others elevated $\mathrm{RO}_{\mathrm{x}}$ overwhelmed a smaller drop in NO (Merced \& Bakersfield) all expressed elevated $\mathrm{P}\left(\mathrm{O}_{3}\right)$. Using these measurements, it is impossible to know whether the enhancements in $\mathrm{RO}_{\mathrm{x}}$ under wildfire influence are generated from transported VOCs or partially oxidized VOCs or from thermally dissociated PAN transported to the sites in the fire plumes. Furthermore, any additional $\mathrm{NO}_{\mathrm{y}}$ interference that is not fully corrected for by the Steinbacher et al. (2007) formula is likely due to the presence of oxidized nitrogen 
species originating from the wildfires and thus has contributed to the ozone enhancement somewhere along its path from the fire to the urban monitoring site even if it is not concurrently increasing the in-situ photochemical production rate.
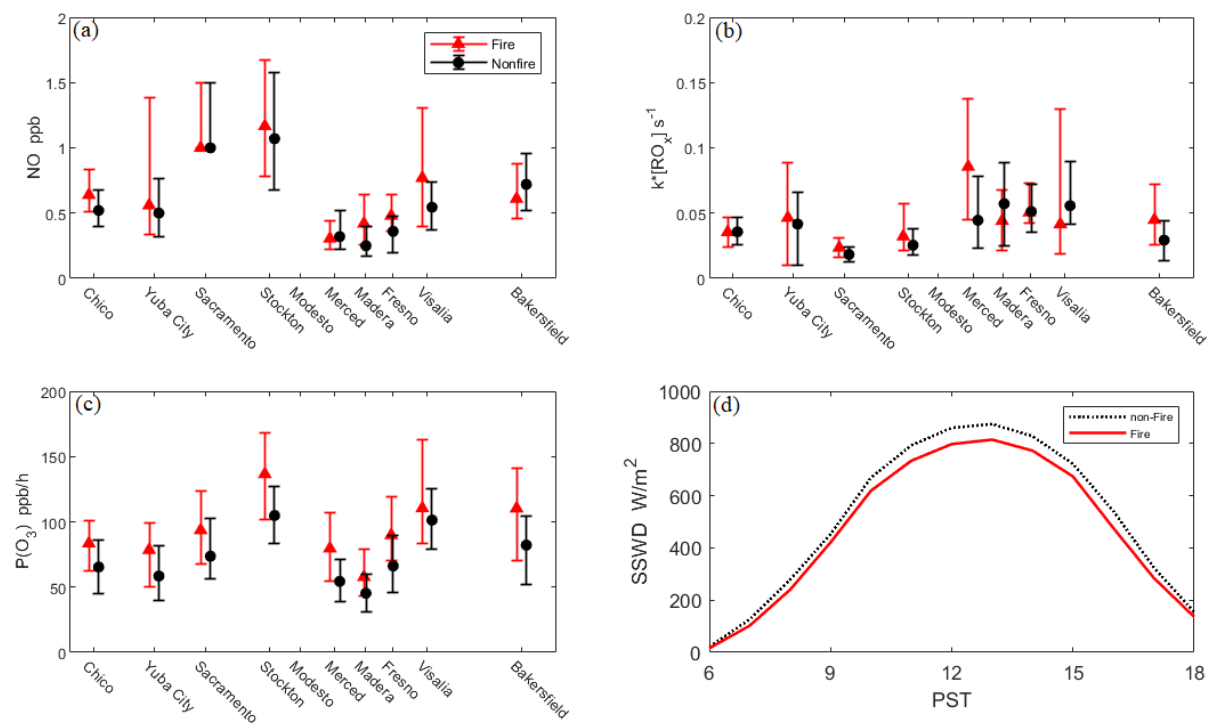

Figure 5: Plots for $\mathrm{NO}$ measurements (a), calculated effective first-order reaction rate $\mathrm{k}\left[\mathrm{RO} \mathrm{x}_{\mathrm{x}}\right]\left(\mathrm{s}^{-1}\right)(\mathrm{b})$, calculated $\mathrm{PO}_{3}(\mathrm{c})$ at each site, and averaged diurnal profiles for SSWD measurements (d). The error bars in (a), (b) and (c) represent $25^{\text {th }}$ and $75^{\text {th }}$ percentiles for 5-hour average between 10:00 and 15:00 PST during wildfire (red) and background (black) days.

$\mathrm{O}_{3}$ production efficiency (OPE) is defined as the enhancement of $\mathrm{O}_{\mathrm{x}}\left(\mathrm{O}_{3}+\mathrm{NO}_{2}\right)$ with respect to $\mathrm{NO}_{\mathrm{z}}\left(\mathrm{NO}_{\mathrm{y}}-\mathrm{NO}_{\mathrm{x}}\right)$. It describes the amount of $\mathrm{O}_{3}$ that is produced per $\mathrm{NO}_{x}$ molecule consumed (Lin et al., 1988; Liu et al., 1987; Olszyna et al., 1994; Trainer et al., 1993). Figure 6 shows scatter plots for $\mathrm{O}_{\mathrm{x}} \mathrm{vs.} \mathrm{NO}_{z}$ in Sacramento (SV) and Fresno (SJV) during the

2016-2020 $\mathrm{O}_{3}$ seasons for both wildfire and background data. The slope value $(\mathrm{m})$ is the enhancement of $\mathrm{O}_{\mathrm{x}}$ with respect to $\mathrm{NO}_{z}$ or OPE. First, we found that the OPE in Sacramento is less than half that in Fresno despite the $\mathrm{NO}_{\mathrm{x}}$ levels being comparable (and even slightly larger in the background data set). This is consistent with the photochemical environment in the SJV having higher VOCs and thus behaving in a more $\mathrm{NO}_{\mathrm{x}}$-limited manner than the SV. Second, neither site shows a significant change in OPE when impacted by wildfires. The OPE is known to monotonically decrease with increasing $\mathrm{NO}_{\mathrm{x}}$ and increase with VOCs under most conditions (Lin et al., 1988; Sillman, 1999). Thus, the insignificant changes in OPE indicates that the enhanced ozone level throughout the $\mathrm{CV}$ are likely due to the concomitant presence of additional $\mathrm{VOCs} / \mathrm{RO}_{\mathrm{x}}$ and $\mathrm{NO}_{\mathrm{x}}$ in approximately comparable measures. 

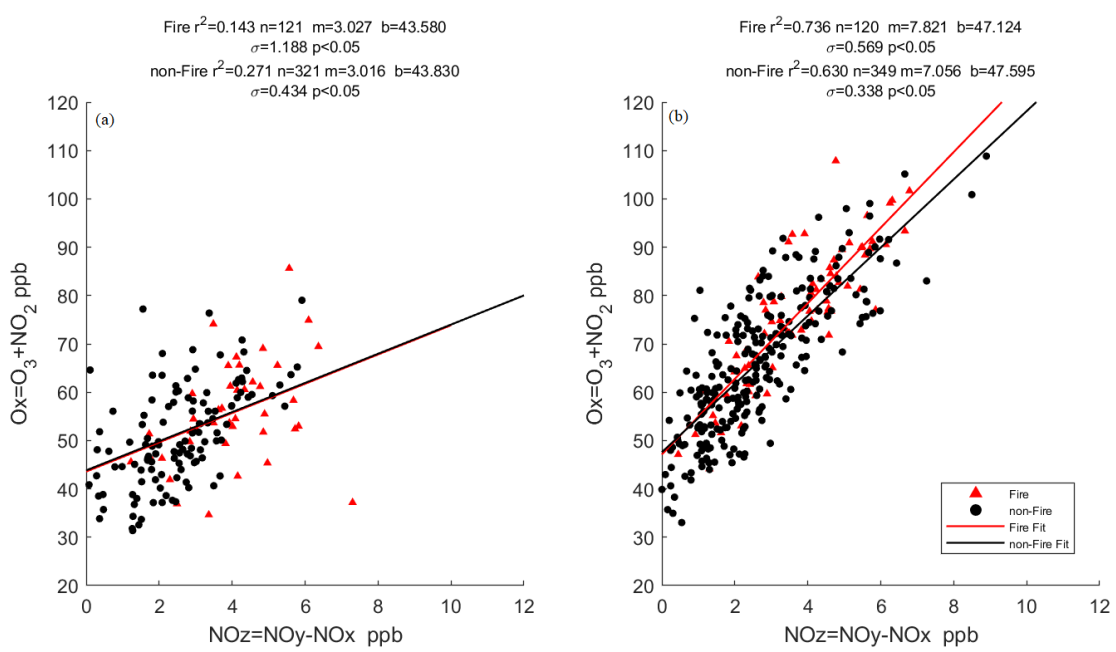

Figure 6: Scatter plot of $\mathrm{O}_{\mathrm{x}}$ versus $\mathrm{NO}_{\mathrm{z}}$ at Sacramento (a) and Fresno (b). The slope of the linear regression (m) represents the OPE. $\mathbf{n}$ is the number of data points in the scatter plot, $\sigma$ is the standard error for the linear regression, and $\mathbf{p}$ is the P-value that represents the rejection of the null hypothesis. In this case, the $\mathbf{P}$-values are less than $\mathbf{0 . 0 5}$, which we interpret as the regressions being statistically significant.

\subsection{Wildfire smoke's influence on boundary layer dynamics}

Measurements of surface heat fluxes $\left(Q_{H}, Q_{E}\right.$, and $\left.\overline{w^{\prime} \theta_{v}^{\prime}}\right)$ and SSWD at Twitchell Wetland (bottom) and Vaira Ranch (top) are shown in Fig. 7. Both the sensible heat flux $Q_{H}$ and buoyancy flux $\overline{w^{\prime} \theta_{v}^{\prime}}$ decrease during the wildfire periods, especially at Twitchell Wetland, where $\overline{w^{\prime} \theta_{v}^{\prime}}$ and $Q_{H}$ are only about half as large on background days. The peak value of $Q_{E}$ at Vaira Ranch decreases by $20 \mathrm{~W} / \mathrm{m}^{2}$ but increases by $20 \%$ on average at Twitchell Wetland. Note that, due to the difference in land types, the soil moisture is significantly higher in Twitchell than Varia, which explains the significantly smaller $Q_{E}$ in Vaira Ranch compared to Twitchell Wetland with a Bowen ratio of 11.7 and 0.6, respectively. Furthermore, the augmented latent heat fluxes at Twitchell Wetland despite the reduced SSWD during wildfire conditions is consistent with an 'oasis effect' observed at the site wherein horizontal advection of warmer/drier air enhances evapotranspiration (Baldocchi et al., 2016). Across all sites, the reduced SSWD,$Q_{H}$, and $\overline{w^{\prime} \theta_{v}^{\prime}}$ below wildfire plumes will weaken the turbulent mixing within the $\mathrm{ABL}$, reducing the $\mathrm{ABL}$ growth rate and height, which in principle would enhance the specific humidity and weaken the surface wind speed because a reduced buoyancy source of turbulent kinetic energy (TKE) will reduce the entrainment fluxes of dry, higher momentum air across the inversion. Our results are consistent with the LES study of aerosol loading in the ABL by Liu et al. (2019), which showed that as aerosol optical depth (AOD) increases, less solar radiation reaches the surface, reducing the surface buoyancy flux, and weakening the entrainment. 

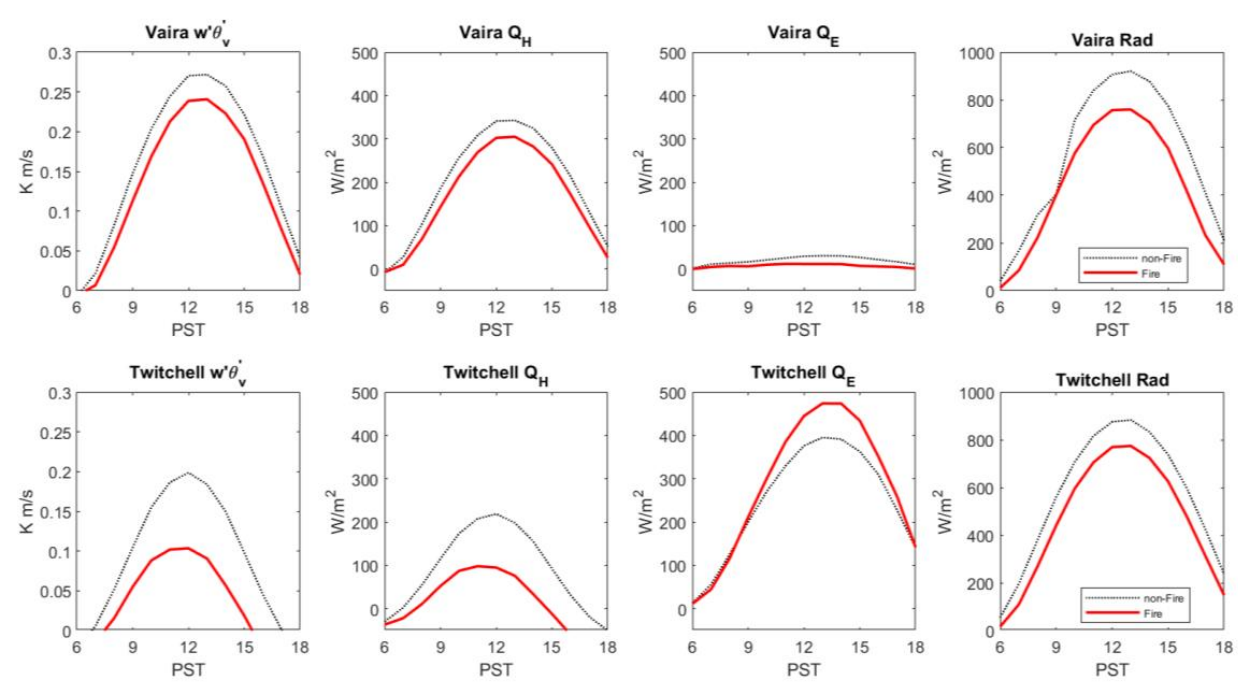

Figure 7: Measurements of buoyancy flux $\left(w^{\prime} \theta_{v}^{\prime}\right)$, sensible heat flux $\left(Q_{\mathrm{H}}\right)$, latent heat flux $\left(\mathrm{Q}_{\mathrm{E}}\right)$, and incoming solar

radiation (SSWD) at Vaira Ranch (top row) and Twitchell Wetland (bottom row). Red solid lines are averaged profiles during wildfire periods (Jun-Sep) from 2016 to 2019. Black dash lines are the averaged profile for non-fire days.

In order to visualize the condition of a polluted ABL during wildfire-influenced periods, Fig. 8 presents the daily averaged aerosol backscatter profiles during wildfire days (a) and background days (b) observed during the California Baseline Ozone Transport Study (Faloona et al., 2020; Langford et al., 2020). The aerosol backscatter profiles are measured

by a Tunable Optical Profiler for Aerosol and Ozone lidar (TOPAZ) that was located in Visalia, CA. During the wildfire periods, the backscatter is seen to be much greater in and above the ABL compared with the background days. We also show the averaged afternoon (13:00 to 15:00 PST) vertical profiles of backscatter in Fig. 8(c), where the aerosol load (i.e., backscatter $\beta$ ) is nearly doubled within the ABL (typically found up to $\sim 600 \mathrm{~m}$ ) during wildfire days. Figure 9 (a) shows the profiles of virtual potential temperature $\left(\theta_{v}\right)$ measured by the RASS located in Visalia. The profile is averaged from 13:00 to 15:00 PST during the summers of 2016-2020 for wildfire days (red) and background days (black) because daily maximum ABL height usually occurs around 14:00 in SJV (Bianco et al., 2011). The $\theta_{v}$ within the entire ABL is consistently about $1-$ $2 \mathrm{~K}$ higher during wildfire days, and the warming is also apparent well above the ABL, which implies that aerosols within the lower valley atmosphere from wildfire plumes absorb solar radiation and warm the ABL and the buffer layer above it without appreciably influencing the stability per se. Liu et al. (2019) also simulate a warmer ABL with aerosols present in their LES, and potential temperature increasing with AOD. While we cannot be certain that the warmer lower troposphere under wildfire influence is solely due to shortwave absorption as opposed to simply climatological differences between wildfire and non-wildfire periods, we do know that surface SSWD and surface heat fluxes are reduced, so the enthalpy difference would likely be found in the lower troposphere. Assuming the $54 \mathrm{Wm}^{-2}$ difference was fully absorbed in the lower $2 \mathrm{~km}$ of the valley atmosphere over the course of 8 hours this would lead to a heating of $\sim 0.8 \mathrm{~K}$. Furthermore, a study by David et al.

435 (2018) show that over a 6-year period in Northern California that wildfire smoke systematically lowers the SSWD by about $120 \mathrm{Wm}^{-2}$ and raises the surface air temperature by about $1 \mathrm{~K}$ for each increase in AOD of 1 . The 5-year averaged diurnal ABL height comparison between wildfire periods and background days is shown in Fig. 9(b) with SSWD comparison shown 
in Fig. 9(c). The midday ABL height is reduced by $80 \mathrm{~m}$ and the SSWD by about $54 \mathrm{~W} / \mathrm{m}^{2}$, on average. Pal and Haeffelin (2015) reported the slope for SSWD versus daily maximum ABL height to be $1.73 \mathrm{~m} / \mathrm{Wm}^{-2}$ from an observatory outside of Paris, and Trousdell et al. (2016) report a similar slope of $1.51 \mathrm{~m} / \mathrm{Wm}^{-2}$ in the SJV. In this study, the observed reduction in ABL height and SSWD due to the wildfire shading effects shown in Fig. $9\left(80 \mathrm{~m} / 54 \mathrm{Wm}^{-2}=1.48 \mathrm{~m} / \mathrm{Wm}^{-2}\right)$ is quantitatively similar to the relationship between ABL height and SSWD in these other studies. It is also worthwhile noting that the altitude of highest backscatter gradient, which is another indicator of ABL height apart from the inversion of $\theta_{v}$ (Hennemuth et al., $2006)$, is actually lower during wildfire days $(\sim 550 \mathrm{~m})$ than on background days $(\sim 650 \mathrm{~m})$. The lowered backscatter inversion also illustrates that the ABL height is stunted due to the shading effect of the wildfire smoke plume. Since the wildfire plumes will weaken the entrainment at the ABL top and lower the ABL height, the rate of dilution from the buffer layer into the $\mathrm{ABL}$ and the volume for pollutant dispersion will also be reduced. Thus, the phenomenon of higher water content and lower wind speed described in section 3.1 could also be the consequence of weaker turbulent mixing within the ABL and the lower ABL heights observed during the wildfire days.
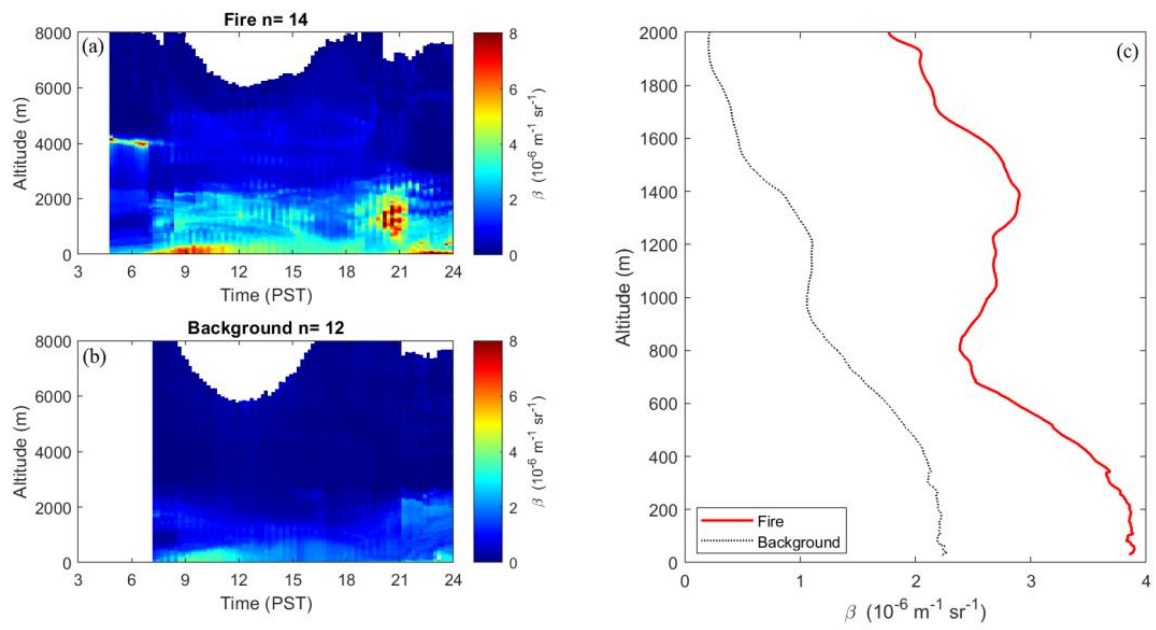

Figure 8: Aerosol backscatter profile for TOPAZ during CABOTS 2016. The plots are averaged diurnal profile for wildfire days (a) and background days (b) during 18 July to 7 August 2016. Averaged vertical backscatter profiles for wildfire days (red) and background days (black) between 13:00 and 15:00 PST are in (c). $n$ is the number of days in the average in each plot. The TOPAZ produces a vertical profile for every 12 mins with a resolution of $\mathbf{5 m}$.

Therefore, the wildfire smoke plays two distinct roles in influencing the ABL dynamics and scalar budgets. First, by attenuating surface insolation the smoke reduces the surface heat fluxes weakening ABL entrainment thereby decreasing the maximum $\mathrm{ABL}$ height, decreasing $\mathrm{ABL}$ wind speeds, and increasing water vapor mixing ratios. The weakened entrainment will likely affect other scalars that are strongly influenced by entrainment dilution such as methane (Trousdell et al., 2019), $\mathrm{N}_{2} \mathrm{O}$, and $\mathrm{CO}_{2}$ all else being equal; however, these trace gases are likewise influenced by wildfire emissions so the impacts are more complex. Second, the smoke absorbs solar radiation warming the air in the ABL (and above) thereby offsetting the reduced surface and entrainment heat fluxes in terms of its impact on air temperature. 

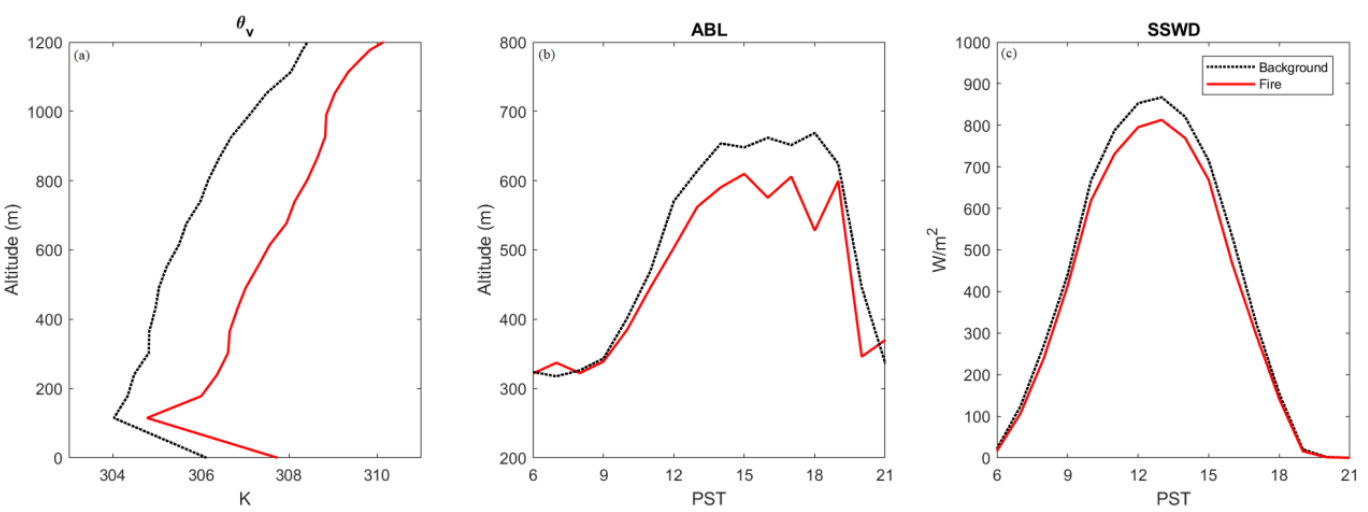

Figure 9: Averaged virtual potential temperature $\left(\theta_{v}\right)$ profile between 13:00 and 15:00 PST (a), diurnal profile for daytime ABL height (b), and diurnal SSWD profile (c) at Visalia during wildfire days (red) and background periods (black) from 2016 to 2020.

\section{Conclusions}

$\mathrm{O}_{3}$ pollution is still an issue in California's urban regions during summer seasons when wildfires are also prone to happen and are becoming larger and more frequent. The wildfires can not only emit primary pollutants like, $\mathrm{CO}, \mathrm{NO}_{\mathrm{x}}$, black carbon, volatile organic compounds, and fine particles, but also provide reactants for the production of secondary pollutants like $\mathrm{O}_{3}$. We use data from ten sites in California's Central Valley region during the summers from 2016-2020 and identified wildfire events by the HMS system and HYSPLIT modeling. On average, the wildfire influenced days in the CV add up to about $20 \%$ of the entire summer time ( 120 days out of 600 days). During these periods we found that MDA8 $\mathrm{O}_{3}$ increases by $6.5 \mathrm{ppb}$ on average with about $5.5 \mathrm{ppb}(10 \%)$ being attributable to the wildfires after correcting for the bias in temperature for wildfire conditions. Further, $\mathrm{NO}_{\mathrm{x}}$ concentrations during daytime increase by $0.9 \mathrm{ppb}(\sim 35 \%)$ and $\mathrm{CO}$ is higher on average by $76 \mathrm{ppb}$ (48\%). The MDA8 $\mathrm{O}_{3}$ increases with $24-\mathrm{hr} \mathrm{PM} 2.5$ at low to moderate concentrations, peaks at $40-55 \mu \mathrm{g} / \mathrm{m}^{3}$, and is more or less independent of $\mathrm{PM}_{2.5}$ at higher concentrations. From our 5-year data analysis, the probability of exceeding the NAAQS of $70 \mathrm{ppb} M D A 8 \mathrm{O}_{3}$ is more than doubled (28\%) during wildfire influence compared to background periods (12\%).

The wildfire events contribute to about $44 \%$ of the total exceedance cases. Daily maximum temperature and specific humidity show enhancement at most sites (averages of $+0.5 \mathrm{~K}$ and $+0.6 \mathrm{gkg}^{-1}$ ), whereas midday windspeed is slightly decreased. The in-situ $\mathrm{P}\left(\mathrm{O}_{3}\right)$ exhibits enhancement at all sites by an average of $26 \%$, despite $j\left(\mathrm{NO}_{2}\right)$ being reduced due to the shading effect of the wildfire plumes. The OPE has insignificant changes in the SJV and unchanged in the SV despite the increase in $\mathrm{NO}_{\mathrm{x}}$ from which we conclude that both the VOCs, and their oxidation products, and $\mathrm{NO}_{\mathrm{x}}$ from wildfire plumes contribute to increasing $\mathrm{O}_{3}$ production.

We analyze surface heat flux measurements from two AmeriFlux sites located in the northern SJV and ABL temperature profiles and ABL heights from a RASS site near Visalia. We find that the surface buoyancy flux decreases by an average of $30 \%$ when overhead wildfire plumes are detected. We also find that the midday ABL height decreases by $80 \mathrm{~m}$ on average with an attenuation of $54 \mathrm{~W} / \mathrm{m}^{2}$ in SSWD. Despite the decreased surface buoyancy fluxes, the $\theta_{v}$ measurements from RASS show that the ABL becomes 1-2 K warmer on average during wildfire influenced periods. This implies that the ABL dynamics will change due to the presence of wildfire plumes and are the net result of two factors. 
First, the shading effect of the wildfire plumes decreases the SSWD, surface heat fluxes, and consequently reduces the ABL height. Second, the additional aerosols in the ABL absorb solar radiation and warm the ABL as well as the 'buffer layer' above it. Since the turbulent entrainment mixing into the ABL and the height itself have critical impacts on the concentration budgets of constituent (e.g., pollutants, water vapor), the weakened turbulent mixing and lowered ABL height will serve to make an already polluted ABL even worse.

\section{Appendices:}

The equation for $\mathrm{j}\left(\mathrm{NO}_{2}\right)$ calculation from surface solar radiation measurements (Trebs et al., 2009).

$j\left(N \mathrm{O}_{2}\right) \downarrow=B_{1} \times G+B_{2} \times G^{2}$

Where $\mathrm{B}_{1}=1.47 * 10^{-5} \mathrm{~W}^{-1} \mathrm{~m}^{2} \mathrm{~s}^{-1}$ and $\mathrm{B}_{2}=-4.84 * 10^{-9} \mathrm{~W}^{-1} \mathrm{~m}^{2} \mathrm{~s}^{-1}$ are polynomial coefficients, $\mathrm{G}$ is solar radiation measurement.

$k_{\mathrm{O}_{3}}=3.47 \exp \left(-\frac{1533}{T}\right) \mathrm{cm}^{3} /$ molecule

Equation (A2) is the Arrhenius function to calculate $k_{\mathrm{O}_{3}}$ based on temperature $T$, the result derived from the function fits the experiment result extremely well through the common temperature range of 283-364K (Lippmann et al., 1980).

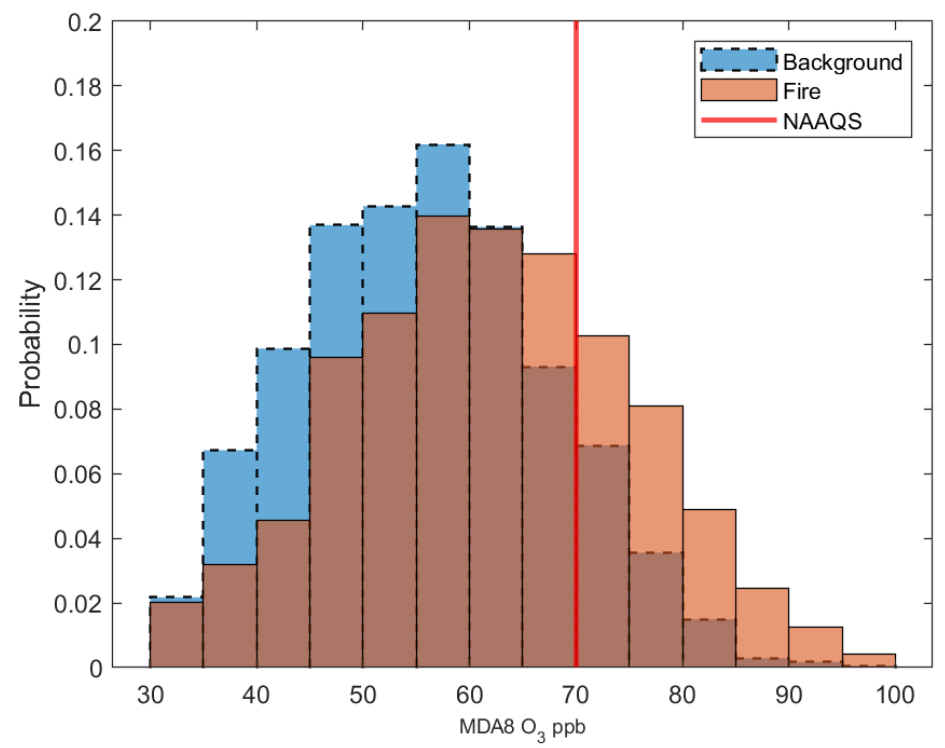

Figure B1. Histograms for MDA8 $\mathrm{O}_{3}$ for wildfire periods (orange) and background periods (blue) during summer (Jun-Sep) from 2016 to 2020. During wildfire periods, almost $28 \%$ of the days exceed the NAAQS of 70 ppb MDA8 $\mathrm{O}_{3}$ (red line) vs only $12 \%$ during background periods. 
https://doi.org/10.5194/acp-2022-144

Preprint. Discussion started: 4 March 2022

(c) Author(s) 2022. CC BY 4.0 License.

(c) (i)
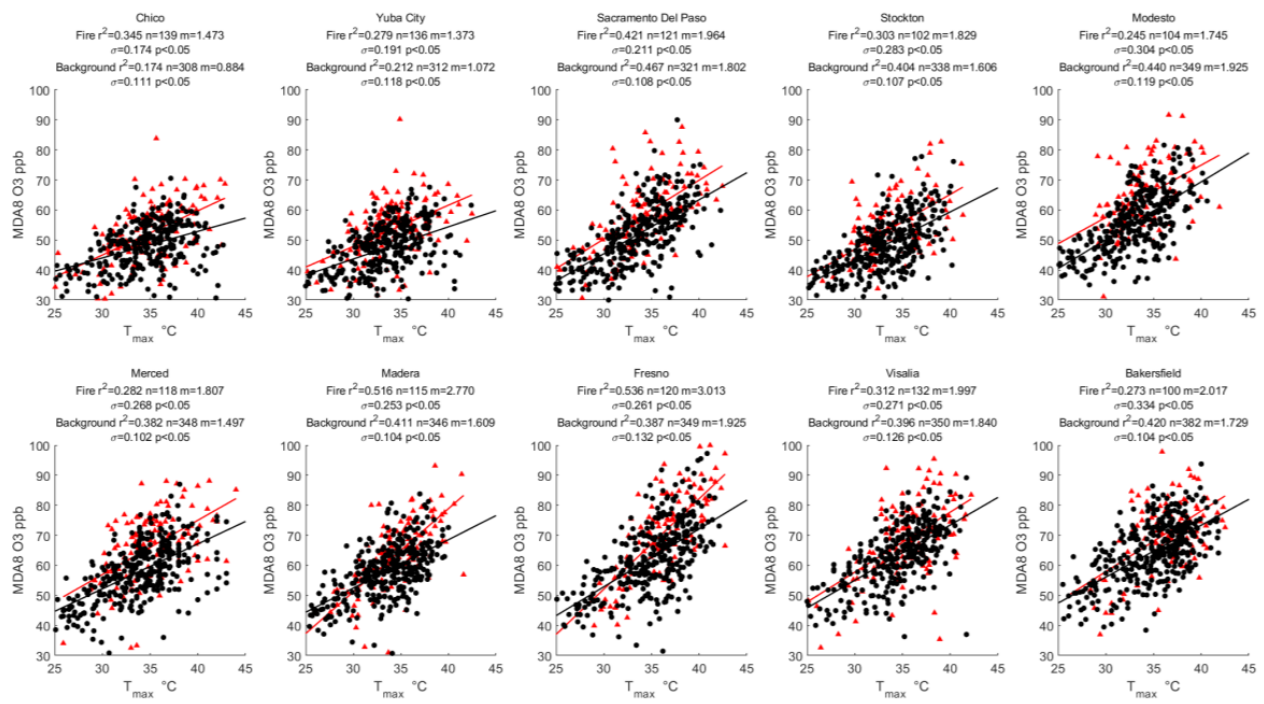

Figure B2. Scatter plot and linear regression for daily maximum temperature versus $\mathrm{MDA8}_{3}$ at each site for wildfire

periods (red) and background periods (black). The $\mathbf{r}^{2}$ above each figure is the coefficient of determination, $m$ is the slope or enhancement ratio, the $\mathbf{n}$ is the number of data points in the regression, the $\boldsymbol{\sigma}$ is the standard error for the linear regression, $\mathbf{p}$ is the $\mathbf{P}$-value that represents the rejection of null hypothesis. 
https://doi.org/10.5194/acp-2022-144

Preprint. Discussion started: 4 March 2022

(c) Author(s) 2022. CC BY 4.0 License.
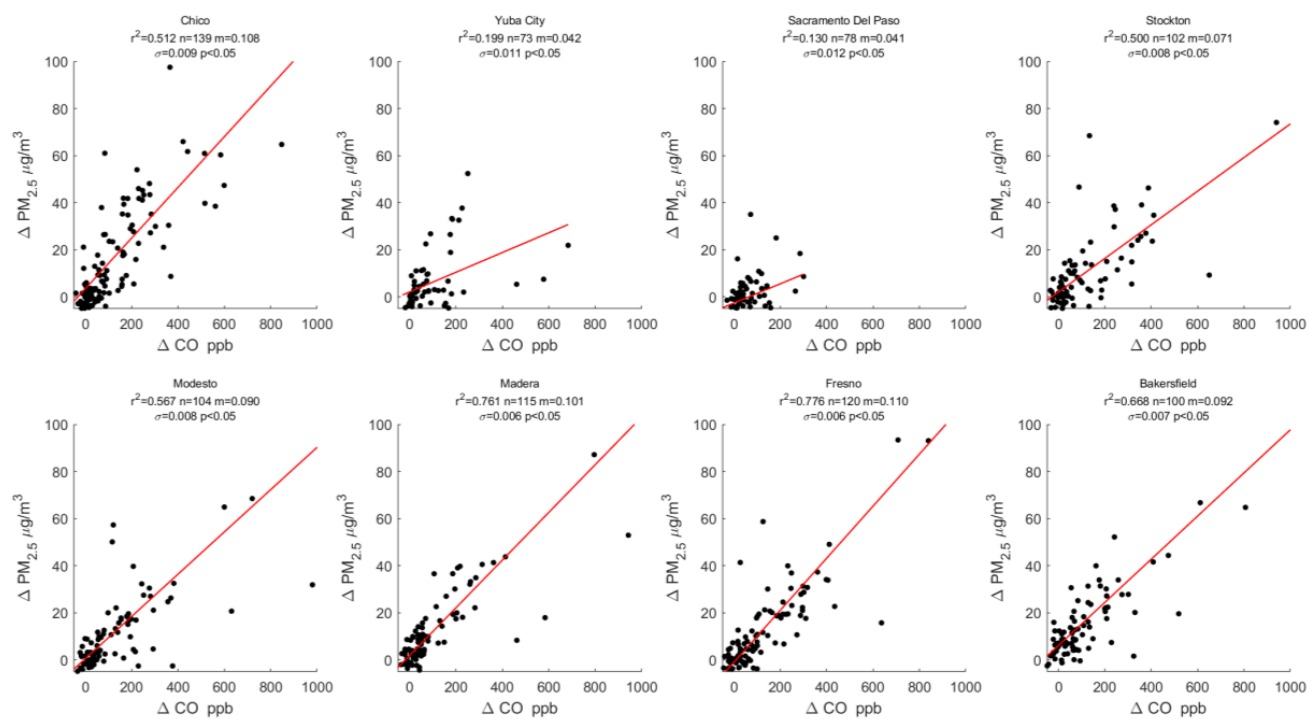

520 Figure B3. Scatter plot and linear regression for $\Delta \mathbf{P M}_{2.5}$ versus $\Delta \mathbf{C O}$ at each site. Enhancements are the differences in afternoon (10:00-15:00 PST) mean values between wildfire and background periods. The $m$ is the slope or enhancement ratio, the $n$ is the number of data points in the regression, the $\sigma$ is the standard error for the linear regression, $p$ is the $P$-value that represent the rejection of null hypothesis.

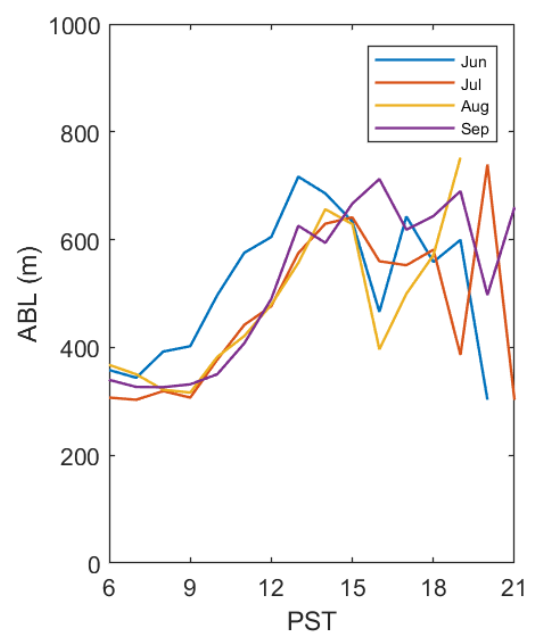

Figure B4. Monthly averaged diurnal ABL height during June to September from 2016 to 2020. 
https://doi.org/10.5194/acp-2022-144

Preprint. Discussion started: 4 March 2022

(c) Author(s) 2022. CC BY 4.0 License.

\begin{tabular}{cc}
\hline Variables & Coefficient \\
\hline Intercept (e) & $-1.32 \mathrm{E}-1$ \\
(NO2) $)_{\mathrm{m}}(\mathrm{a})$ & $1.32 \mathrm{E}-1$ \\
O3 (b) & $2.71 \mathrm{E}-2$ \\
Month (c) & \\
Jan & 0 \\
Feb & -0.012 \\
Mar & 0.258 \\
Apr & 0.380 \\
May & 0.239 \\
Jun & -0.092 \\
Jul & -0.105 \\
Aug & -0.135 \\
Sep & 0.050 \\
Oct & -0.050 \\
Nov & -0.274 \\
Dec & -0.026 \\
day (d) & $-1.87 \mathrm{E}-1$
\end{tabular}

Table C1. Constants in Eq. (6) for $\mathrm{NO}_{2}$ correction (Steinbacher et al., 2007). The result is from the multiple linear regression model at Taenikon site.

530

535

\begin{tabular}{ll}
\hline Site & Wildfire Days \\
\hline Chico & 139 \\
Yuba City & 136 \\
Sacramento & 121 \\
Stockton & 102 \\
Modesto & 104 \\
Merced & 118 \\
Madera & 115 \\
Fresno & 120 \\
Visalia & 132 \\
Bakersfield & 100 \\
\hline
\end{tabular}

Table C2. Number of the wildfire influenced days at each site during summer (Jun-Sep) 2016-2020. 
https://doi.org/10.5194/acp-2022-144

\begin{tabular}{lllll}
\hline $24-\mathrm{hr} \mathrm{PM}$ & & CV & SV & SJV \\
\hline$<5 \mu \mathrm{g} / \mathrm{m}^{3}$ & Fire & 20 & 11 & 9 \\
& Background & 480 & 169 & 311 \\
\hline $5-10 \mu \mathrm{g} / \mathrm{m}^{3}$ & Fire & 200 & 66 & 134 \\
& Background & 1669 & 429 & 1240 \\
\hline $10-15 \mu \mathrm{g} / \mathrm{m}^{3}$ & Fire & 272 & 74 & 198 \\
& Background & 919 & 243 & 676 \\
\hline $15-20 \mu \mathrm{g} / \mathrm{m}^{3}$ & Fire & 182 & 61 & 121 \\
& Background & 229 & 67 & 162 \\
\hline $20-30 \mu \mathrm{g} / \mathrm{m}^{3}$ & Fire & 163 & 67 & 96 \\
& Background & 54 & 17 & 37 \\
\hline $30-40 \mu \mathrm{g} / \mathrm{m}^{3}$ & Fire & 125 & 34 & 91 \\
& Background & 6 & 0 & 6 \\
\hline $40-55 \mu \mathrm{g} / \mathrm{m}^{3}$ & Fire & 98 & 41 & 57 \\
& Background & 0 & 0 & 0 \\
\hline $55-70 \mu \mathrm{g} / \mathrm{m}^{3}$ & Fire & 34 & 11 & 23 \\
& Background & 1 & 1 & 0 \\
\hline $70-100 \mu \mathrm{g} / \mathrm{m}^{3}$ & Fire & 42 & 12 & 30 \\
& Background & 1 & 1 & 0 \\
\hline$>100 \mu \mathrm{g} / \mathrm{m}^{3}$ & Fire & 39 & 12 & 27 \\
& Background & 1 & 0 & 1 \\
\hline
\end{tabular}

\begin{tabular}{cccc}
\hline Site & Fire & Non-fire & Percentage of Fire \\
\hline CHICO & 4 & 1 & 80 \\
YUBA CITY & 4 & 0 & 100 \\
SACRAMENTO & 18 & 12 & 60 \\
STOCKTON & 6 & 5 & 55 \\
MODESTO & 29 & 33 & 47 \\
MERCED & 49 & 39 & 56 \\
MADEARA & 33 & 27 & 55 \\
FRESNO & 63 & 87 & 42 \\
VISALIA & 63 & 98 & 39 \\
BAKERSFIELD & 58 & 120 & 33 \\
Total & 327 & 422 & 44 \\
\hline
\end{tabular}

Table C4. Number and percentage of the exceedances of $70 \mathrm{ppb} \mathrm{MDA8} \mathrm{O}_{3}$ at each site. 


\section{Data Availability}

All air quality and meteorological data (section 2.1) are download from Air Quality and Meteorological Information System

of California Air Resources Board's (CARB) website.

$\mathrm{NO}_{\mathrm{y}}$ data (section 3.2) are downloaded from AirNow-Tech website.

Solar radiation measurements (section 2.3) are download from CIMIS websites.

RASS data collected near Visalia (section 2.4) was downloaded from the website of NOAA's Physical Sciences Laboratory.

Surface fluxes data (section 2.4) of Twitchell Island and Vaira Ranch are downloaded from AmeriFlux website.

TOPAZ data from NOAA Earth System Research Laboratory Chemical Sciences Division during 2016 CABOTS are used in section 3.3.

\section{Competing Interests:}

The authors declare that they have no conflict of interest.

\section{Acknowledgements}

This work was supported by the California Agricultural Experiment Station, Hatch project CA-D-LAW-2229-H.

The Tunable Optical Profiler for Aerosol and oZone (TOPAZ) lidar data are provided by NOAA Earth System Research Laboratory Chemical Sciences Division during California Baseline Ozone Transport study (CABOTS) in 2016.

\section{References}

Ainsworth, E.: A. Understanding and improving global crop response to ozone pollution, The Plant Journal, 90(5), 886-897, https://doi.org/10.1111/tpj.13298, 2017.

AirNow-Tech: Data Queries, MADIS, https://www.airnowtech.org/data/index.cfm, 2020.

Akagi, S. K., Yokelson, R. J., Burling, I. R., Meinardi, S., Simpson, I., Blake, D. R., ... \& Urbanski, S.: Measurements of reactive trace gases and variable $\mathrm{O} 3$ formation rates in some South Carolina biomass burning plumes, https://doi.org/10.5194/acp-13-1141-2013, 2013.

575 Alvarado, M. J., Logan, J. A., Mao, J., Apel, E., Riemer, D., Blake, D., ... \& Wooldridge, P. J.: Nitrogen oxides and PAN in plumes from boreal fires during ARCTAS-B and their impact on ozone: an integrated analysis of aircraft and satellite observations, Atmospheric Chemistry and Physics, 10(20), 9739-9760, https://doi.org/10.5194/acp-10-9739-2010, 2010. Arya, P. S.: Introduction to micrometeorology, Elsevier, 2001. 
Baker, K. R., Woody, M. C., Valin, L., Szykman, J., Yates, E. L., Iraci, L. T., ... \& Campuzano-Jost, P.: Photochemical model evaluation of 2013 California wild fire air quality impacts using surface, aircraft, and satellite data, Science of The Total Environment, 637, 1137-1149, https://doi.org/10.1016/j.scitotenv.2018.05.048, 2018.

Baldocchi, D., Knox, S., Dronova, I., Verfaillie, J., Oikawa, P., Sturtevant, C., ... \& Detto, M.: The impact of expanding flooded land area on the annual evaporation of rice. Agricultural and Forest Meteorology, 223, 181-193, https://doi.org/10.1016/j.agrformet.2016.04.001, 2016.

Baylon, P., Jaffe, D. A., Hall, S. R., Ullmann, K., Alvarado, M. J., \& Lefer, B. L.: Impact of biomass burning plumes on photolysis rates and ozone formation at the Mount Bachelor Observatory, Journal of Geophysical Research: Atmospheres, 123(4), 2272-2284, https://doi.org/10.1002/2017JD027341, 2018.

Baylon, P., Jaffe, D. A., Wigder, N. L., Gao, H., \& Hee, J.: Ozone enhancement in western US wildfire plumes at the Mt. Bachelor Observatory: The role of NOx, Atmospheric Environment, 109, 297-304, https://doi.org/10.1016/j.atmosenv.2014.09.013, 2015.

Berkowicz, R., \& Prahm, L. P.: Evaluation of the profile method for estimation of surface fluxes of momentum and heat, Atmospheric Environment (1967), 16(12), 2809-2819, https://doi.org/10.1016/0004-6981(82)90032-4, 1982.

Bianco, L., Djalalova, I. V., King, C. W., \& Wilczak, J. M.: Diurnal evolution and annual variability of boundary-layer height and its correlation to other meteorological variables in California's Central Valley, Boundary-layer meteorology, 140(3), 491-511, DOI: 10.1007/s10546-011-9622-4, 2011.

Brasseur, G. P., Orlando, J. J., \& Tyndall, G. S.: Atmospheric chemistry and global change, (p. 654), New York: Oxford Univ. Press, 1999.

Brey, S. J., \& Fischer, E. V.: Smoke in the city: how often and where does smoke impact summertime ozone in the United States?, Environmental science \& technology, 50(3), 1288-1294, https://doi.org/10.1021/acs.est.5b05218, 2016.

Brey, S. J., Barnes, E. A., Pierce, J. R., Swann, A. L., \& Fischer, E. V.: Past variance and future projections of the environmental conditions driving western US summertime wildfire burn area. Earth's future, 9(2), e2020EF001645, https://doi.org/10.1029/2020EF001645, 2021.

Brey, S. J., Barnes, E. A., Pierce, J. R., Wiedinmyer, C., \& Fischer, E. V.: Environmental conditions, ignition type, and air quality impacts of wildfires in the southeastern and western United States. Earth's future, 6(10), 1442-1456, https://doi.org/10.1029/2018EF000972, 2018.

Brey, S. J., Ruminski, M., Atwood, S. A., \& Fischer, E. V.: Connecting smoke plumes to sources using Hazard Mapping System (HMS) smoke and fire location data over North America, Atmospheric Chemistry and Physics, 18(3), 1745-1761, https://doi.org/10.5194/acp-18-1745-2018, 2018.

Briggs, N. L., Jaffe, D. A., Gao, H., Hee, J. R., Baylon, P. M., Zhang, Q., ... \& Cary, R. A.: Particulate matter, ozone, and nitrogen species in aged wildfire plumes observed at the Mount Bachelor Observatory, Aerosol and Air Quality Research, 16(12), DOI: 10.4209/aaqr.2016.03.0120, 2016.

Buysse, C. E., Kaulfus, A., Nair, U., \& Jaffe, D. A.: Relationships between particulate matter, ozone, and nitrogen oxides during urban smoke events in the western US. Environmental science \& technology, 53(21), 12519-12528, https://doi.org/10.1021/acs.est.9b05241, 2019. 
615 California Air Resources Board: Air Quality and Meteorological Information System, https://www.arb.ca.gov/aqmis2/aqmis2.php, 2020.

California Irrigation Management Information System: Solar Radiation Measurements, CIMIS Stations Reports, https://cimis.water.ca.gov/WSNReportCriteria.aspx, 2020.

David, A. T., Asarian, J. E., \& Lake, F. K.: Wildfire smoke cools summer river and stream water temperatures. Water Resources Research, 54(10), 7273-7290, https://doi.org/10.1029/2018WR022964, 2018.

de Gouw, J. A., \& Lovejoy, E. R.: Reactive uptake of ozone by liquid organic compounds, Geophysical Research Letters, 25(6), 931-934, https://doi.org/10.1029/98GL00515, 1998.

Dunlea, E. J., Herndon, S. C., Nelson, D. D., Volkamer, R. M., San Martini, F., Sheehy, P. M., ... \& Molina, M. J.: Evaluation of nitrogen dioxide chemiluminescence monitors in a polluted urban environment. Atmospheric Chemistry and Physics, 7(10), 2691-2704, https://doi.org/10.5194/acp-7-2691-2007, 2007.

Faloona, I. C., Chiao, S., Eiserloh, A. J., Alvarez, R. J., Kirgis, G., Langford, A. O., ... \& Yates, E. L.: The California Baseline Ozone Transport Study (CABOTS), Bulletin of the American Meteorological Society, 101(4), E427-E445, https://doi.org/10.1175/BAMS-D-18-0302.1, 2020.

Fischer, E. V., Jaffe, D. A., Reidmiller, D. R., \& Jaegle, L.: Meteorological controls on observed peroxyacetyl nitrate at Mount Bachelor during the spring of 2008, Journal of Geophysical Research: Atmospheres, 115(D3), https://doi.org/10.1029/2009JD012776, 2010.

Griffin, R. J., Beckman, P. J., Talbot, R. W., Sive, B. C., \& Varner, R. K.: Deviations from ozone photostationary state during the International Consortium for Atmospheric Research on Transport and Transformation 2004 campaign: Use of measurements and photochemical modeling to assess potential causes, Journal of Geophysical Research: Atmospheres, 112(D10), https://doi.org/10.1029/2006JD007604, 2007.

Hazard Mapping System Fire and Smoke Product, https://www.ospo.noaa.gov/Products/land/hms.html, December 2020.

Hennemuth, B., \& Lammert, A.: Determination of the atmospheric boundary layer height from radiosonde and lidar backscatter. Boundary-Layer Meteorology, 120(1), 181-200, https://doi.org/10.1007/s10546-005-9035-3, 2006.

Jaffe, D. A., \& Wigder, N. L.: Ozone production from wildfires: A critical review, Atmospheric Environment, 51, 1-10, https://doi.org/10.1016/j.atmosenv.2011.11.063, 2012.

Jenkin, M. E., \& Hayman, G. D.: Photochemical ozone creation potentials for oxygenated volatile organic compounds: sensitivity to variations in kinetic and mechanistic parameters. Atmospheric environment, 33(8), 1275-1293, https://doi.org/10.1016/S1352-2310(98)00261-1, 1999.

Langford, A. O., Alvarez, R. J., Brioude, J., Caputi, D., Conley, S. A., Evan, S., et al.: Ozone production in the Soberanes smoke haze: Implications for air quality in the San Joaquin Valley during the California Baseline Ozone Transport Study, Journal of Geophysical Research: Atmospheres, 125, e2019JD031777, https://doi.org/10.1029/2019JD031777, 2020. Leighton, P. A.: Photochemistry of Air Pollution, Academic Press: New York, Vol. 9, 1961.

Leukauf, D., Gohm, A., \& Rotach, M. W.: Quantifying horizontal and vertical tracer mass fluxes in an idealized valley during daytime, Atmospheric Chemistry and Physics, 16(20), 13049, https://doi.org/10.5194/acp-16-13049-2016, 2016. 

2014: quantifying the roles of rising Asian emissions, domestic controls, wildfires, and climate, Atmospheric Chemistry \& Physics, 17(4), https://doi.org/10.5194/acp-17-2943-2017, 2017.

Lin, X., Trainer, M., \& Liu, S. C.: On the nonlinearity of the tropospheric ozone production, Journal of Geophysical Research: Atmospheres, 93(D12), 15879-15888, https://doi.org/10.1029/JD093iD12p15879, 1988.

K, International Journal of Chemical Kinetics, 12(8), 547-554, https://doi.org/10.1002/kin.550120805, 1980.

Liu, C., Fedorovich, E., Huang, J., Hu, X. M., Wang, Y., \& Lee, X.: Impact of aerosol shortwave radiative heating on entrainment in the atmospheric convective boundary layer: A large-eddy simulation study, Journal of the Atmospheric Sciences, 76(3), 785-799, https://doi.org/10.1175/JAS-D-18-0107.1, 2019.

Liu, S. C., Trainer, M., Fehsenfeld, F. C., Parrish, D. D., Williams, E. J., Fahey, D. W., ... \& Murphy, P. C.: Ozone production in the rural troposphere and the implications for regional and global ozone distributions, Journal of Geophysical Research: Atmospheres, 92(D4), 4191-4207, https://doi.org/10.1029/JD092iD04p04191, 1987.

Mannschreck, K., Gilge, S., Plass-Duelmer, C., Fricke, W., \& Berresheim, H.: Assessment of the applicability of NO-NO 2O 3 photostationary state to long-term measurements at the Hohenpeissenberg GAW Station, Germany. Atmospheric Chemistry and Physics, 4(5), 1265-1277, https://doi.org/10.5194/acp-4-1265-2004, 2004.

Mannschreck, K., Klemp, D., Kley, D., Friedrich, R., Kühlwein, J., Wickert, B., ... \& Slemr, F.: Evaluation of an emission inventory by comparisons of modelled and measured emission ratios of individual HCs, CO and NOx, Atmospheric Environment, 36, 81-94. https://doi.org/10.1016/S1352-2310(02)00211-X, 2002.

McClure, C. D., \& Jaffe, D. A.: Investigation of high ozone events due to wildfire smoke in an urban area, Atmospheric Environment, 194, 146-157, https://doi.org/10.1016/j.atmosenv.2018.09.021, 2018.

National Report of Wildland Fires and Acres Burned by State, https://www.nifc.gov/fire-information/statistics, December 2020.

NOAA Physical Sciences Laboratory: 915 MHz Wind Profiler, Profiler Network Data \& Image Library, https://psl.noaa.gov/data/obs/datadisplay/, 2020.

Olszyna, K. J., Bailey, E. M., Simonaitis, R., \& Meagher, J. F.: O3 and NO y relationships at a rural site, Journal of Geophysical Research: Atmospheres, 99(D7), 14557-14563, https://doi.org/10.1029/94JD00739, 1994.

Pahlow, M., Kleissl, J., \& Parlange, M. B.: Atmospheric boundary-layer structure observed during a haze event due to forestfire smoke, Boundary-layer meteorology, 114(1), 53-70, DOI: 10.1007/s10546-004-6350-z, 2005.

Pal, S., \& Haeffelin, M.: Forcing mechanisms governing diurnal, seasonal, and interannual variability in the boundary layer depths: Five years of continuous lidar observations over a suburban site near Paris, Journal of Geophysical Research: Atmospheres, 120(23), 11-936, https://doi.org/10.1002/2015JD023268, 2015.

Parrish, D. D., Trainer, M., Holloway, J. S., Yee, J. E., Warshawsky, M. S., Fehsenfeld, F. C., ... \& Moody, J. L.: Relationships between ozone and carbon monoxide at surface sites in the North Atlantic region, Journal of Geophysical Research: Atmospheres, 103(D11), 13357-13376, https://doi.org/10.1029/98JD00376, 1998. 
685 Pfister, G. G., Wiedinmyer, C., \& Emmons, L. K.: Impacts of the fall 2007 California wildfires on surface ozone: Integrating local observations with global model simulations, Geophysical Research Letters, 35(19), https://doi.org/10.1029/2008GL034747, 2008.

Potter, B. E.: Atmospheric properties associated with large wildfires, International Journal of Wildland Fire, 6(2), 71-76, https://doi.org/10.1071/WF9960071, 1996.

Pusede, S. E., Gentner, D. R., Wooldridge, P. J., Browne, E. C., Rollins, A. W., Min, K. E., ... \& Henry, S. B.: On the temperature dependence of organic reactivity, nitrogen oxides, ozone production, and the impact of emission controls in San Joaquin Valley, California, Atmospheric Chemistry and Physics, 14(7), 3373-3395, https://doi.org/10.5194/acp-143373-2014, 2014.

Reid, J. S., Koppmann, R., Eck, T. F., \& Eleuterio, D. P.: A review of biomass burning emissions part II: intensive physical properties of biomass burning particles, Atmospheric Chemistry and Physics, 5(3), 799-825, https://doi.org/10.5194/acp5-799-2005, 2005.

Rolph, G. D., Draxler, R. R., Stein, A. F., Taylor, A., Ruminski, M. G., Kondragunta, S., ... \& Davidson, P. M.: Description and verification of the NOAA smoke forecasting system: the 2007 fire season, Weather and Forecasting, 24(2), 361-378. https://doi.org/10.1175/2008WAF2222165.1, 2009.

Rombout, P. J., Lioy, P. J., \& Goldstein, B. D.: Rationale for an eight-hour ozone standard, Journal of the Air Pollution Control Association, 36(8), 913-917, https://doi.org/10.1080/00022470.1986.10466130, 1986.

Ruminski, M., Kondragunta, S., Draxler, R., \& Zeng, J.: Recent changes to the hazard mapping system, In Proceedings of the 15th International Emission Inventory Conference, Vol. 15, p. 18, 2006.

Sara Knox, Jaclyn Hatala Matthes, Joseph Verfaillie, Dennis Baldocchi: AmeriFlux BASE US-Twt Twitchell Island, Ver. 65, AmeriFlux AMP, (Dataset), https://doi.org/10.17190/AMF/1246140, 2018.

Selimovic, V., Yokelson, R. J., McMeeking, G. R., \& Coefield, S.: In situ measurements of trace gases, PM, and aerosol optical properties during the 2017 NW US wildfire smoke event, Atmospheric Chemistry and Physics, 19(6), 3905-3926, https://doi.org/10.5194/acp-19-3905-2019, 2019.

Selimovic, V., Yokelson, R. J., McMeeking, G. R., \& Coefield, S.: Aerosol mass and optical properties, smoke influence on O3, and high NO3 production rates in a western US city impacted by wildfires, Journal of Geophysical Research: Atmospheres, 125(16), e2020JD032791, https://doi.org/10.1029/2020JD032791, 2020.

Sillman, S., \& Samson, P. J.: Impact of temperature on oxidant photochemistry in urban, polluted rural and remote environments, Journal of Geophysical Research: Atmospheres, 100(D6), 11497-11508, https://doi.org/10.1029/94JD02146, 1995.

Sillman, S.: The relation between ozone, NOx and hydrocarbons in urban and polluted rural environments, Atmospheric Environment, 33(12), 1821-1845, https://doi.org/10.1016/S1352-2310(98)00345-8, 1999.

Simon, H., Reff, A., Wells, B., Xing, J., \& Frank, N.: Ozone trends across the United States over a period of decreasing NOx and VOC emissions. Environmental science \& technology, 49(1), 186-195, https://doi.org/10.1021/es504514z, 2015.

Singh, H. B., Cai, C., Kaduwela, A., Weinheimer, A., \& Wisthaler, A.: Interactions of fire emissions and urban pollution over California: Ozone formation and air quality simulations, Atmospheric Environment, 56, 45-51, https://doi.org/10.1016/j.atmosenv.2012.03.046, 2012. 
Siyan Ma, Liukang Xu, Joseph Verfaillie, Dennis Baldocchi: AmeriFlux BASE US-Var Vaira Ranch- Ione, Ver. 16-5, AmeriFlux AMP, (Dataset), https://doi.org/10.17190/AMF/1245984, 2021.

Standard operating procedures for ambient air monitoring: https://www.atmospheric-chemistry-andphysics.net/submission.html\#manuscriptcomposition, May 2021.

Stavros, E. N., Abatzoglou, J. T., McKenzie, D., \& Larkin, N. K.: Regional projections of the likelihood of very large wildland fires under a changing climate in the contiguous Western United States, Climatic Change, 126(3-4), 455-468, https://doi.org/10.1007/s10584-014-1229-6, 2014.

Stein, A. F., Draxler, R. R., Rolph, G. D., Stunder, B. J., Cohen, M. D., \& Ngan, F.: NOAA's HYSPLIT atmospheric transport and dispersion modeling system, Bulletin of the American Meteorological Society, 96(12), 2059-2077, https://doi.org/10.1175/BAMS-D-14-00110.1, 2015.

Steinbacher, M., Zellweger, C., Schwarzenbach, B., Bugmann, S., Buchmann, B., Ordóñez, C., ... \& Hueglin, C.: Nitrogen oxide measurements at rural sites in Switzerland: Bias of conventional measurement techniques, Journal of Geophysical Research: Atmospheres, 112(D11), https://doi.org/10.1029/2006JD007971, 2007.

Steiner, A. L., Davis, A. J., Sillman, S., Owen, R. C., Michalak, A. M., \& Fiore, A. M.: Observed suppression of ozone formation at extremely high temperatures due to chemical and biophysical feedbacks, Proceedings of the National Academy of Sciences, 107(46), 19685-19690. https://doi.org/10.1073/pnas.1008336107, 2010.

Tan, Z., Lu, K., Dong, H., Hu, M., Li, X., Liu, Y., ... \& Wu, Y.: Explicit diagnosis of the local ozone production rate and the ozone-NOx-VOC sensitivities, Science bulletin, 63(16), 1067-1076, https://doi.org/10.1016/j.scib.2018.07.001, 2018. ozone with NOy in photochemically aged air, Journal of Geophysical Research: Atmospheres, 98(D2), 29172925, https://doi.org/10.1029/92JD01910, 1993.

Trebs, I., Bohn, B., Ammann, C., Rummel, U., Blumthaler, M., Königstedt, R., ... \& Andreae, M. O.: Relationship between the $\mathrm{NO}_{2}$ photolysis frequency and the solar global irradiance, Atmospheric Measurement Techniques, 2(2), 725-739, https://doi.org/10.5194/amt-2-725-2009, 2009.

Trousdell, Justin F., Stephen A. Conley, Andy Post, and Ian C. Faloona: Observing entrainment mixing, photochemical ozone production, and regional methane emissions by aircraft using a simple mixed-layer framework, Atmospheric Chemistry and Physics, 16, no. 24, 15433-15450, https://doi.org/10.5194/acp-16-15433-2016, 2016.

Val Martín, M. V., Honrath, R. E., Owen, R. C., Pfister, G., Fialho, P., \& Barata, F.: Significant enhancements of nitrogen oxides, black carbon, and ozone in the North Atlantic lower free troposphere resulting from North American boreal wildfires, Journal of Geophysical Research: Atmospheres, 111(D23), https://doi.org/10.1029/2006JD007530, 2006.

Volz-Thomas, A., Pätz, H. W., Houben, N., Konrad, S., Mihelcic, D., Klüpfel, T., \& Perner, D.: Inorganic trace gases and peroxy radicals during BERLIOZ at Pabstthum: An investigation of the photostationary state of NOx and O3, Journal of Geophysical Research: Atmospheres, 108(D4), PHO-4, https://doi.org/10.1029/2001JD001255, 2003. temperature inversion: Measurements and radiative transfer calculations, Journal of Applied Meteorology, 35(10), 17031715, https://doi.org/10.1175/15200450(1996)035<1703:VPOAAR>2.0.CO;2, 1996. 
https://doi.org/10.5194/acp-2022-144

Preprint. Discussion started: 4 March 2022

(C) Author(s) 2022. CC BY 4.0 License.

(c) (i)

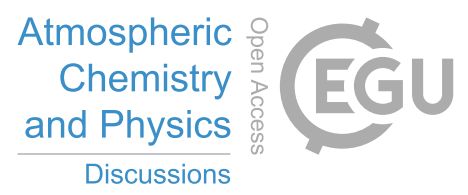

Zhang, L., Jacob, D. J., Yue, X., Downey, N. V., Wood, D. A., \& Blewitt, D.: Sources contributing to background surface ozone in the US Intermountain West, Atmospheric Chemistry and Physics, https://doi.org/10.5194/acp-14-5295-2014,

760 2014.

Zhong, S., Whiteman, C. D., \& Bian, X.: Diurnal evolution of three-dimensional wind and temperature structure in California's Central Valley, Journal of Applied Meteorology, 43(11), 1679-1699, https://doi.org/10.1175/JAM2154.1, 2004. 